\title{
İSLÂM HUKUKUNDA KADIN İÇ ÜREME ORGANLARI NAKLININ HÜKMÜ
}

\author{
İbrahim PAÇACI ${ }^{1}$
}

\begin{abstract}
Özet
Her evli çift çocuk sahibi olmak ister. Fakat bazı çiftler, tabii yollarla anne-baba olamamaktadır. Günümüzde geliştirilen yardımcı üreme yöntemleriyle, bu çiftlerin pek çoğu çocuk sahibi olabilmektedir. Üreme organlarının nakli, söz konusu yöntemlerdendir. Üreme organları naklinin hükmü, genetik özellikleri taşıııp taşımamasına bağlıdır. Buna göre fallop tüplerinin nakli caiz değildir. Kadının kendisinden alınarak dondurulan yumurtalık/yumurtalık dokusunun daha sonra kendisine nakledilmesi (ototransplantasyon) caizdir. Fakat başkasına ait yumurtalık/yumurtalık dokusunun tranplantasyonu, dokunun alındığı kadının genetik özelliklerini naklettiği için caiz değildir. Yumurtalık fonksiyonları yeterli olduğu halde, uterus faktörlü infertilite sebebiyle çocuk sahibi olamayan kadınlara rahim nakli ise caizdir. Başkasına ait yumurtalık dokusunun nakli caiz olmamakla birlikte yapılması durumunda, çocuğun nesebi, kendisini doğuran anne ve eşinden sabit olur. Bunun yanında çocuk ile yumurtalık dokusu alınan kadın arasında, evlilik engeli meydana gelir.
\end{abstract}

Anahtar kelime: İnfertilite, fallop tüpleri nakli, yumurtalık nakli, rahim nakli, organ nakli.

\section{THE TRANSPLANTATION OF WOMEN'S INTERNAL REPRODUCTIVE ORGAN IN ISLAMIC LAW}

\begin{abstract}
Every married couple wants to have a child. But some couples, can't have a child from natural ways. With the help of reproductive methods developed today, many of these couples can have children. Transplantation of reproductive organs is one of these methods.Reproductive organs transport depends on carrying genetic traits. Accordingly, transplantation of fallopian tubes is not permissible. It is permissible to transfer the ovarian / ovarian tissue from the woman herself to the frozen tissue (autotransplantation). But transplantation of someone else's ovarian / ovarian tissue is not permissible because it transduces the genetic properties of the woman from which the tissue is taken. Women with adequate ovarian function are allowed to undergo uterine transplantation if they can not have children due to uterine factor infertility. Transplantation of ovarian tissue from someone else is not permissible. In the case of ovarian tissue transplantation belongs to someone else, it comes from the lineage of the mother who bore the child herself and her partner. In addition, between the child and the woman with ovarian tissue transplantation, the marriage becomes obstructive.
\end{abstract}

Keywords: İnfertility, fallopian tubes transplantation, ovarian transplantation, uterus transplantation, organ transplantation.

\footnotetext{
${ }^{1}$ Doç. Dr. Aksaray Üniversitesi İslami İlimler Fakültesi, ipacaci@hotmail.com
} 


\section{GIRIŞ}

Her canlının fitratında, neslini koruma ve devam ettirme içgüdüsü bulunmaktadır. Dolayısıyla her insan da, çocuk sahibi olup neslini devam ettirmek ister. Kur'ân-1 Kerim'de bu arzunun fitrî olduğuna işaret edilerek, "Kadınlar, çocuklar, ... insanlara çekici kılınmıı̧tır..." buyrulmaktadır. Başka bir ayette de, "Mal ve çocuklar dünya hayatının süsüdür..." ${ }^{3}$ denmektedir. İnsanın bu arzusu Kur'ân'da tabii karşılanarak, Allâh’tan, kendilerine göz nuru olacak eş ve çocuklar istemeleri tavsiye edilmiştir ${ }^{4}$. Bu çerçeveden olarak, bazı peygamber ve salih kişilerin, Allâh'tan iyi bir çocuk ve temiz nesiller istediği Kur'ân'da anlatılmaktadır5. Bütün dinlerde ve hukuk sistemlerinde meşru kılınan evliğin İslâm'a göre gayelerinden biri, belki de en önemlisi, çocuk sahibi olmaktır. Nitekim Rasûlullâh (s.a.s.), "Evlenin çoğalın, ben diğer ümmetlere sizin çokluğunuzla övüneceğim." buyurmuşturø.

Böyle olmasına rağmen her çift çocuk sahibi olamamaktadır. Toplumda "kısırlık" diye tanımlanan bu durum, tıp dilinde "infertilite" olarak adlandırılmaktadır. Ínfertilite ise, üreme çağındaki çiftlerin bir yıl boyunca çocuk sahibi olmayı istemelerine rağmen gebeliğin oluşmaması veya gebeliği sürdürememe durumudur. ${ }^{7}$

Çocuklarının olmaması çiftleri ve onların ailelerini derinden etkilemektedir. Çünkü çocuk sahibi olmak, neslin devamını sağlamanın yanında, sosyolojik, psikolojik, manevî ve ahlâkî boyutları olan hayatî bir anlama sahiptir. ${ }^{8}$ Bu sebeple çocuğu olmayan çiftler, bütün imkânlarını seferber ederek çare bulmaya çalışmaktadır. Tabii yollarla çocuk sahibi olamayan çiftler, tıbbın geliştirdiği yardımcı yöntemlerle artık çocuk sahibi olabilmektedir. Günümüzde, ovulasyonun (yumurtlama) uyarılması, oositlerin (yumurtaların) toplanması, oosit ve embriyo kültürü, embriyoların dondurularak saklanması ve embriyo transfer tekniklerinde meydana gelen gelişmelerle, daha önce çocuk sahibi olamayan pek çok çift, evlat sahibi olma imkânı elde

\footnotetext{
2 Âl-i İmrân 3/14.

${ }^{3}$ Kehf $18 / 46$.

${ }^{4}$ Furkân 25/74.

${ }^{5}$ Bk. Bakara 2/128; Âl-i İmrân 3/38; Hûd 11/71; İbrâhim 14/40.

${ }^{6}$ İbn Mâce, nikâh, 1, (H.No: 1836).

${ }^{7}$ Jane Özcan, Invitro Fertilizasyon Planlanan Zayıf Yanıtlı Hastalarda Uygulanan Mikrodoz Protokolü İle Mikrodoz Stop Protokolünün Karşılaştırılması, (Yayınlanmamış Uzmanlık Tezi), İstanbul 2005, 5; Özlem Aşc1, Nezihe Kızılkaya Beji, "İnfertilite Danışmanlığı”, İstanbul Üniversitesi Florence Nightingale Hemşirelik Dergisi, İstanbul, 20 (2012), 2, 154; Şeyhmus Tunç, Spontan Yoldan Ve Yardımcı Üreme Teknikleri Ille Gebe Kalan Hastaların Maternal, Fetal ve Perinatal Özelliklerinin Karşılaştırılması, (Yayınlanmamış Uzmanlık Tezi), Malatya 2014, 4.

${ }^{8}$ Gülüşan Göce, "Tüp Bebek Tedavisi Almış Kadınların Dinî Başa Çıkma Süreçleri ve Dini Yaşantıları Üzerine Nitel Bir Araştırma”, İstanbul Üniversitesi İlahiyat Fakültesi Dergisi, İstanbul, 32 (2005), 166; Aşc1, Kızılkaya Beji, "İnfertilite Danışmanlığı”, 154.
} 
etmiştir. ${ }^{9} \mathrm{Bu}$ çerçevede geliştirilen pek çok yardımcı üreme yöntemi bulunmaktadır: Aşılama, tüp bebek uygulamas1, mikro enjeksiyon, yumurta nakli, embriyo nakli, embriyonun dondurularak saklanması bunlar arasında sayılabilir. Ayrıca yumurtalık (over) ve rahim (uterus) nakli de, infertilite tedavisi arasında yer almaktadır. ${ }^{10}$

Söz konusu yardımcı üreme yöntemlerinden, tüp bebek uygulaması ile ilgili çalışmalar, hayvanlar üzerinde 19. yüzyılda başlamış olmakla birlikte, insanlar üzerinde yapılan ilk başarılı tüp bebek çalışması 1976 yılında gerçekleştirilmiş ve o günden günümüze büyük bir gelişme kaydetmiştir $^{11}$. Tüp bebek uygulamasının üzerinden uzun bir süre geçtiği için bu konu, İslâm hukuku açısından pek çok toplantı ve çalışmada değerlendirilmiştir. ${ }^{12}$ Fakat ilk başarılı taze yumurtalık (over) nakli 2005 yılında $^{13}$ ve ilk başarılı rahim (uterus) nakli ise 2011 yılında ${ }^{14}$ gerçekleştirildiği için, üreme organlarının nakli henüz yeni bir konudur. Bu çalışmada, kadın üreme organlarının nakli konusu ele alınarak İslâm hukuku açısından değerlendirilecektir.

\footnotetext{
${ }^{9}$ Tunç, Spontan Yoldan Ve Yardımcı Üreme Teknikleri İle Gebe Kalan Hastaların Maternal, Fetal ve Perinatal Özelliklerinin Karşılaştırılması, 19; Yasemin Erol, Yapay Döllenme Yöntemleri ve Taşıyıcı Annelik, (Yayınlanmamış Doktora Tezi), Konya 2011, 11-14.

${ }^{10}$ Çağdaş Doğan, Prematür Ovaryan Yetmezlikle Xpd Ve Xrccl Dna Tam ir Gen Polimorfizminin İlişkisi, (Yayınlanmamış Uzmanlık Tezi) Malatya 2011, 35-36; Erol, Yapay Döllenme Yöntemleri ve Taşlyıcı Annelik, 11-51; Mehmet Musa Aslan, Üniversite Hastanesine Başvuran Fertil ve Infertil Kadınların Yumurta Donasyonu Hakkındaki Düşünceleri, (Yayınlanmamış Uzmanlık Tezi), Edirne 2016, 11-12; Tunç, Spontan Yoldan Ve Yardımcı Üreme Teknikleri İle Gebe Kalan Hastaların Maternal, Fetal ve Perinatal Özelliklerinin Karşılaştırılması, 18; Tuğba Uğurlu, Antioksidanların Uterus Transplantasyonunda Angiogenezise Etkileri, (Yayınlanmamış Yüksek Lisans Tezi), Ankara 2017, 1-2, 26-27; Ruşen Öztürk, Ümran Sevil, "Uterus Transplantasyonu ve Etik", Gümüşhane Üniversitesi Sağllk Bilimleri Dergisi, Gümüşhane, 2, (2013), 4/538-539.

${ }^{11}$ Cihan Çetin, M. Turan Çetin, "Dünden Bugüne Yardımla Üreme Teknikleri”, Arşiv Kaynak Tarama Dergisi, Adana, 23, (2014), 1/152-154.

${ }^{12}$ Mesela bk. Mecma'u'l-Fıkhi'l-İslâmî'nin22-28 Aralık 1985 tarihinde Cidde'de gerçekleştirdiği ikinci dönem toplantısında alınan 5 sayılı "Tüp Bebek" kararı, Mecelletü'l-Mecma'i'l-Flkhi'l-İslâmî, Cidde 1986, II, 381; Mecma'u'l-Fıkhi'l-İslâmî'nin11-16 Ekim 1986 tarihinde Amman'da gerçekleştirdiği üçüncü dönem toplantısında alınan 4 sayılı “Tüp Bebek” kararı, Mecelletü'l-Mecma 'i'l-Fıkhi'l-İslâmî, yy. 1987, III, 515-516; Bekir b. Abdullah Ebû Zeyd, “Turuku'l-İncâb fi't-Tibbi'l-Hadîsi ve Hukmuha'şŞer'iyyu”, Mecelletü'l-Mecma'i'l-Fıkhi'l-İslâmî, yy. 1987, III, 429-458; Muhammed Ali el-Bâr, "elKadâyâ'l-Ahlâkiyyetü'n-Nâcimetü ani't-Tehakkümi fî Takniyyâti'l-İncâb (et-Telkîhu'l-İstinâ'î)", Mecelletü'l-Mecma'i'l-Fikhi'l-İslâmî, yy. 1987, III, 461-468.

${ }^{13}$ Çetin ve Çetin, "Dünden Bugüne Yardımla Üreme Teknikleri”, 154.

${ }^{14}$ Uğurlu, Antioksidanların Uterus Transplantasyonunda Angiogenezise Etkileri, 27.
} 


\section{DOKU VE ORGAN NAKLI}

Doku ve organ nakli (transplantasyon); vücutta kaybedilen ya da görevini yapamayan bir organ veya dokunun, canlı veya ölüden alınan aynı işlevi yerine getirecek sağlam bir organ veya doku ile değiştirilmesi işlemidir. Başka bir ifadeyle transplantasyon, hücre, doku veya organın bir kişiden diğerine veya aynı kişinin vücudunda başka bir bölgeye nakledilmesidir. ${ }^{15}$

Organ nakli tıpta, çok eskiden beri ilgi duyulan bir konudur. MÖ 2-3. yüzyıllarda, o zamanki cerrahi yöntemlerle organ naklinin denendiğinden bahsedilmektedir. ${ }^{16}$ İlk başarılı organ nakli denemesi 16. yüzyılda İtalya'da gerçekleştirilmiş; 18. yüzyılda diş, tendon ve deri nakli yapılmıştır. ${ }^{17}$ Fakat modern anlamda organ nakli 19. yüzyılda başlamış ve hızlı bir gelişme kaydetmiştir. Günümüzde kalp, kalp kapakçığı, akciğer, karaciğer, böbrek, pankreas, dalak, kemik, kemik iliği, endokrin bezler, damar, kan, deri, hatta yüz nakli gibi pek çok organ ve doku nakli gerçekleştirilebilmektedir. ${ }^{18}$

Bazı Şâfiî kaynaklarında, namazın şartları ve namazı bozan şeyler konusunda, kemik, et, deri naklinden bahsedilmekte ve zaruret bağlamında değerlendirilmektedir ${ }^{19}$. Fakat organ nakli,

15 İrfan Yüce, “Organ Nakli”, DIA, Ankara 2007, XXXIII, 373; Pınar Doğan, Afyon Kocatepe Üniversitesi Öğrencilerinin Organ Băğışı Konusundaki Bilgi Tutum Ve Davranışları, (Yayınlanmamış Yükseklisans Tezi), Afyon 2009, 10; Selami Kara, Zeliha Salman, Kurtuluş Öngel, "Süleyman Demirel Üniversitesi Tıp Fakültesi Sağlık Personelinin Organ Bağışına Bakışı", Ankara Sağllk Hizmetleri Dergisi, Ankara, 11, (2012), 1/34; Birand Taneri, Acil Servisde Acil Tip Hekimlerinin Organ Bağışı Sürecinde Yönetim, Duyarlılık ve Farkındalıkları, (Yayınlanmamış Uzmanlık Tezi), Ankara 2015, 5.

${ }^{16}$ Doğan, Afyon Kocatepe Üniversitesi Öğrencilerinin Organ Bağışı Konusundaki Bilgi Tutum Ve Davranışları, 11; Taneri, Acil Tip Hekimlerinin Organ Bağışı Sürecinde Yönetim, Duyarlılık ve Farkındalıkları, 7; Abdullah b. Muhammed et-Tayyâr, Abdullah b. Muhammed el-Mutallık, Muhammed b. İbrâhîm el-Mûsâ, el-Fıkhu'l-Müyesser en-Nevâzilu't-Tibbiyyetü'l-Mu'âsıra, Riyad $2012,29$.

${ }^{17}$ Doğan, Afyon Kocatepe Üniversitesi Öğrencilerinin Organ Bă̆ışı Konusundaki Bilgi Tutum Ve Davranışlarl, 11-12; Taneri, Acil Tıp Hekimlerinin Organ Bağış̧ Sürecinde Yönetim, Duyarlılık ve Farkındalıkları, 7; Abdullah et-Tayyâr vd., el-Fikhu'l-Müyesser, 29.

${ }^{18}$ Doğan, Afyon Kocatepe Üniversitesi Öğrencilerinin Organ Bağışı Konusundaki Bilgi Tutum Ve Davranışları, 11-12; Taneri, Acil Tip Hekimlerinin Organ Bağışı Sürecinde Yönetim, Duyarlılık ve Farkındalıkları, 7; Abdullah et-Tayyâr vd., el-Fikhu'l-Müyesser, 29; Selami Kara vd., "Süleyman Demirel Üniversitesi Tıp Fakültesi Sağlık Personelinin Organ Bağışına Bakışı”, 34.

${ }^{19}$ Muhyiddîn Ebû Zekeriyyâ Yahyâ b. Şeref en-Nevevî, Minhâcu't-Tâlibîn ve Umdetü 'l-Müftîn, Dâru'lMinhâc, Beyrut 2005, 106; Şemsüddin Muhammed b. Ebû'l-Abbâs Ahmed b. Hamza İbn Şihabiddîn er-Remlî, Nihâyetü'l-Muhtâc ilâ Şerhi'l-Minhâc fi'l-Fikhi alâ Mezhebi 'l-İmâm eş-Şâfî̀, Dâru Kütübi'lİlmiyye, Beyrut 1993, II, 21; Şemsüddîn Muhammed b. el-Hatîb eş-Şirbînî, Muğni'l-Muhtâc ilâ Ma'rifeti Me'âni Elfâzi 'l-Minhâc, Dâru'l-Ma'rife, Beyrut 1997, I, 292-293; Muhammed b. Ahmed eşŞirbînî, el-Büceyrimi ale 'l-Hatîb (el-İknâ' fì Halli Elfâzi Ebî Şucâ'), Dâru'l-Kütübi'l-İlmiyye, Beyrut 1996, II, 253-254; Kemalüddin Ebu'l-Bekâ Muhammed b. Mûsâ b. Îsâ ed-Demîrî, en-Necmü'l-Vehhâc fỉ Şerhi'l-Minhâc, Dâru'l-Minhâc, yy. 2004, II, 205-206; Sa'îd b. Muhammed Bâ-Alî Bâişin ed-Dev'anî 
19. yüzyıldan sonra gelişmeye başladığı ve yakın zamanlarda yaygınlaştığı için, bu konu İslâm bilginleri tarafından 20. yüzyılda tartışılmaya başlanmıştır. Bu dönemde, pek çok bilimsel heyet ve kurulda organ nakli gündeme gelerek tartışılmış ve çözüm üretilmeye çalışılmıştır.

Organ naklini, insan bedenine yetkisiz ve haksız müdahale, yaratılışı değiştirmek, haramla tedavi olarak değerlendiren Abdülaziz b. Abdullah İbn Bâz (ö. 1999), İbn Useymîn, Enver Mahmûd Debûr, Abdurrahman el-Adevî, Safvet Hasan Lutfî, Şa'ravî gibi bir kısım İslâm hukukçusu, organ naklinin caiz olmadığını söylemiştir ${ }^{20}$. Buna karşılık pek çok ulusal ve uluslar arası bilimsel heyet ve kurulda organ nakli konusu gündeme gelerek tartışı1mış ve tedaviyle ilgili nasslar ${ }^{21}$ ile "Zaruretler, memnû' olan şeyleri mubah kılar." ${ }^{22}$ gibi zaruretler konusundaki fikhın genel ilkeleri dikkate alınarak organ naklinin caiz olduğu kabul edilmiştir ${ }^{23}$. Diyanet İşleri Başkanlığı Din işleri Yüksek Kurulu'nun 3 Mart 1980 tarih ve 396/13 sayılı kararı; Rabitatü'l-Alemi'l-İslâmî bünyesindeki İslâm Fıkıh Akademisi'nin 19-28 Ocak 1985 (28/47/5/1405 h.) tarihlerinde Mekke'de düzenlediği sekizinci dönem toplantısında alınan karar; İslâm Konferansı Örgütü bünyesindeki İslâm Fıkıh Akademisi'nin 6-11 Şubat 1988 (1823/6/1408) tarihlerinde Cidde'de düzenlediği dördüncü dönem toplantısında alınan 1 sayılı karar; Suudî Arabistan Krallığg'ndaki Hey’etü Kibâri'l-Ulemâ'nın 6/12/1402 tarih ve 99 sayılı kararı; Kuveyt Vakıflar ve Din İşleri Bakanlığı Fetva Kurulu'nun 24 Aralık 1979 tarih ve 13Z/79 sayılı, ayrıca 14 Eylül 1981 tarih ve 87/81 sayılı kararları bunlar arasında sayılabilir²4.

İslâm bilginlerinin çoğunluğu, organ naklini caiz olan tedavi şekilleri arasında değerlendirmekle birlikte, doğabilecek bazı sakıncaları göz önünde bulundurarak bu tedavi yöntemine bazı sınırlandırmalar getirmişlerdir. Bu bağlamda;

İKÖ İslâm Fıkıh Akademisi’nce 6-11 Şubat 1988 (18-23/6/1408) tarihlerinde Cidde'de düzenlenen dördüncü dönem toplantısında;

el-Hadramî, Şerhu'l-Mukaddimeti'l-Hadramiyye (Büşra'l-Kerîm bi-Şerhi Mesâili't-Ta'lîm), Dâru'lMinhâc, Beyrut 2004, 256.

${ }^{20}$ Abdullah et-Tayyâr vd., el-Fıkhu'l-Müyesser, 22-23; Şenkîtî, Ahkâmu'l-Cerâhati't-Tıbbiyye, 354355.

${ }^{21}$ Bk. Mâide 5/32; Buhârî, "İcâre", 18, "Bed'ü'l-Halk" 10; “Tıb”, 1-57; Müslim, "Selâm”, 69-91; Tirmizi, "T1b", 1-35; Ebû Dâvûd, "T1b", 1-24.

${ }^{22}$ Mecelle-i Ahkâm-1 Adliyye, Madde: 21

${ }^{23}$ Organ nakli konusundaki tartışmalarla ilgili geniş bilgi için bk. Mecelletü'l-Mecma 'i'l-Fıkhi'l-İslâmî, Cidde 1988, IV, 89-510.

${ }^{24}$ Bk. Mecelletü' 'l-Mecma 'i'l-Fıkhi'l-İslâmî, IV, 509-510; Abdullah et-Tayyâr vd., el-Fikhu'l-Müyesser, 31; Muhammed b. Muhammed el-Muhtâr eş-Şenkîtî, Ahkâmu'l-Cerâhati't-Tıbbiyye ve'l-Âsâru'lMüterettibetü aleyhâ, Cidde 1994, 355-356; “Organ Nakli”, https://kurul.diyanet.gov.tr/Karar-MutalaaCevap/9669/organ-nakli (03.02.2018). 
a) Sağlayacağı yararın, oluşturacağı zarardan fazla olması; kaybedilen, şekli bozulan veya fonksiyonunu yitirilen bir organın eski haline iadesi; kişiyi psikolojik veya bedensel zorluk ve sıkıntılara sokan kusur ve noksanlıkların giderilmesi amacına yönelik olması kaydıyla kişinin kendi vücudundan alınan bir organın başka bir yere nakledilmesinin,

b) Donörün tam eda ehliyetine sahip olması ve hukuken gerekli diğer şartların da bulunması kaydıyla, kan, deri gibi kendiliğinden yenilenebilen organ veya dokuların naklinin,

c) Hastalık sebebiyle alınan gözün korneası gibi, herhangi bir sebeple vücuttan alınan bir organ veya organ parçasının, başka bir kimseye nakledilmesinin,

Caiz olduğu,

d) Kalp gibi, kişinin yaşaması kendisine bağlı olan bir organın, canlı kişiden alınarak başkasına nakledilmesinin,

e) İki gözün korneasının da nakli gibi, kişinin hayatını devam ettirmesi kendisine bağlı olmamakla birlikte, beden fonksiyonlarından birini yok edecek şekilde organ naklinin,

Caiz olmadığ1,

f) Ölmeden önce kendisinin veya öldükten sonra yakınlarının izin vermesi şartıyla, ölmüş kişilerden hayati organların da nakledilebileceği,

g) Nakledilecek organ karşılığında ücret alınmasının caiz olmadığı,

h) Bunların dışında kalan durumların ise, tartışma konusu olduğu, araştırılması gerektiği, Karara bağlanmıştır ${ }^{25}$.

Diyanet İşleri Başkanlığı Din İşleri Yüksek Kurulunun 03/03/1980 tarih ve 396/13 sayılı kararında da,

"1. Zaruret halinin bulunması, yani hastanın hayatını veya hayatî bir uzvunu kurtarmak için, bundan başka çaresi olmadığının, meslekî ehliyet ve dürüstlüğüne güvenilen bir tabip tarafindan tespit edilmesi,

2. Hastalığın bu yoldan tedavi edilebileceğine tabibin zann-1 galibinin bulunması,

3. Organ veya dokusu alınan kişinin, bu işlemin yapıldığı esnada ölmüş olması,

4. Toplumun huzur ve düzeninin bozulmaması bakımından organ veya dokusu alınacak

25 “4/1 nolu Organ Nakli kararı”, Mecelletü'l-Mecma'i’l-Fıkhi'l-İslâmî, IV, 509-510. 
kişinin sağlı̆̆ında (ölmeden önce) buna izin vermiş olması veya hayatta iken aksine bir beyanı olmamak şartıyla, yakınlarının rızasının sağlanması,

5. Alınacak organ veya doku karşılığında hiçbir şekilde ücret alınmaması, Tedavisi yapılacak hastanın da kendisine yapılacak bu nakle razı olması,”

Kaydıyla organ naklinin caiz olduğu kabul edilmiştir²6.

\section{KADIN ÜREME ORGANLARI}

Kadın üreme organları, karın boşluğunda bulunur ve iç üreme organları, dış üreme organları ve ikincil organlar olmak üzere üç kısımda incelenir ${ }^{27}$. Bu çalışmada, söz konusu organlardan infertilite tedavisi kapsamında transplantasyonu yapılabilecek olan yumurtalıklar, fallop tüpleri ve rahim ele alınacaktır.

\section{Fallop Tüpleri (Tuba Uterina)}

Fallop tüpleri, rahmin sağ ve sol köşeleriyle yumurtalıklar arasında uzanan, 11-12 cm. uzunluğunda boru şeklinde iki organdır. Tüplerin duvarı -içten dışa- mukoza, kas ve seroza olmak üzere üç tabakadan oluşmaktadır. İç yüzeyi tüylü hücrelerle kaplıdır ve bunlar salgı yaparlar. Tüplerin yumurtalık tarafındaki uçları serbest olup saçak biçimindedir. Bu saçaklar ovarlardan çıkan yumurtayı yakalayıp tüpe alır. Tüplerin içindeki salgı ve tüyler sayesinde yumurta rahme doğru ilerler. Tüpler döllenmenin olduğu yerdir. Yumurta ve spermler tüplerde karşılaşır ve döllenme burada gerçekleşir. Burada döllenen yumurta (zigot) rahim boşluğuna gelir. ${ }^{28}$

\section{Yumurtalıklar (Ovarium)}

Yumurtalıklar, kadınların temel üreme organlarıdır. Karın boşluğunun alt kısmında, uterusun her iki yanında, tüplerin saçaksı uçlarına yakın bir yerde, pelvis boşluğun iki yan duvarında asılı olarak dururlar. Yumurtalıklar her biri, 3-5 cm boyunda, 2-3 cm eninde, ortalama 4-6 gr. Ağırlığında, beyaz sedef görünümde, badem şeklinde çift organdır.

Yumurtalıkların; a) ovulasyon (yumurtlama) ve b) kadın hormonları (östrojenprogesteron) salgılamak olmak üzere iki önemli görevi vardır. Her kız çocuğu, yumurtalıklarında yüzlerce yumurta hücresiyle dünyaya gelir. Ergenlik dönemiyle birlikte, her

\footnotetext{
26 “Organ Nakli”, https://kurul.diyanet.gov.tr/Karar-Mutalaa-Cevap/9669/organ-nakli (03.02.2018)

${ }^{27}$ Belma Derman Semiz, İnsan Anatomisi ve Fizyolojisi, Marmara Üniversitesi Yayınları, İstanbul 1990, 165.

${ }^{28}$ Semiz, Insan Anatomisi ve Fizyolojisi, 167; Milli Eğitim Bakanlığı, Üreme Sistemi, Ankara 2012, 16; Milli Eğitim Bakanlığı (MEB), Çocuk Gelişimi ve Eğitimi Anne ve Çocuk Sağllğı 1, Ankara 2012, 7.
} 
ay sırayla yumurtalıklardan biri olgun bir yumurta (ovum) hücresi çıkarır. Gebelik ve doğumu izleyen ilk iki ay hariç, menopoz dönemine kadar yumurtlama aralıksız sürer. Ovariumdan atılan yumurta, tüplerin saçakları tarafindan tutularak, tüpe alınır. ${ }^{29}$

\section{Rahim (Uterus)}

Rahim, karın boşluğunda mesaneyle rektum arasında yer alan, ters armut biçiminde içi boş gebelik organıdır. Rahim 7-9 cm. uzunlukta, $5 \mathrm{~cm}$ ende, 2-2,5 cm kalınlıkta, kaslardan oluşan esnek bir organdır. Gebelikte büyür. Rahim üç bölümden oluşur. Fallop tüplerinin arasında kalan kısma fundus denir. Rahmin en büyük parçası, korpus denen gövde boşluğudur. Rahmin altında yer alan rahim ağzı (serviks) ise en küçük parçası olup döl yoluna bir kanalla açılmaktadır.

Rahim üç tabakadan oluşmaktadır. Dış tabaka (parametrium), bağ dokulardan oluşmuştur. Rahmin dış yüzeyinin kayganlaştırarak hareketliliğini sağlar. Üzerinde bol miktarda damar, sinir ve lenf ağları bulunur. Orta tabaka (myometrium), düz kas liflerinden oluşur. Embriyoyu korumak ve kasılarak bebeğin doğmasına yardımcı olmak bu tabakanın görevidir. Rahmin iç boşluğunu, endometrium denilen ince zar tabakası örter. Gebelik olmadığında, her ay bu tabaka dökülerek dışarı atılır. Buna regl/adet kanaması (mensturasyon)denir ve bu menopoz dönemine kadar devam eder. Tüplerde döllenme meydana gelirse, oluşan zigot, tüplerden gelerek buraya yerleşir ve yaklaşık kırk hafta burada kalır. Rahim gebelikte çok büyür ve bu esnada kanama olmaz. ${ }^{30}$

Rahmin önemli fonksiyonları şunlardır: a) Kanamayla dökülen endometrium tabakayı 23 gün içinde yenilemek, b) Embriyonun endometriuma yerleşmesini sağlayıp, onu korumak, c) Orta tabakadaki düz kas liflerinin kasılmasıyla doğuma yardımcı olmak, d) Embrionun beslenmesini ve oksijenini sağlamak, ondan karbondioksit ve artıkları almaktır. ${ }^{31}$

\section{KADIN ÜREME ORGANI NAKLINIIN HÜKMÜ}

Çocuğu olamayan çiftlerin, çocuk sahibi olabilmeleri için uygulanan tedavi yöntemlerinden biri de üreme organlarının naklidir. Üreme organlarının nakli, diğer organlar gibi değildir. Bunun için üreme organları naklinin, genel olarak, organ nakli içerisinde kabul

\footnotetext{
${ }^{29}$ Semiz, İnsan Anatomisi ve Fizyolojisi, 165-167; MEB, Üreme Sistemi, 15, 27-28; MEB, Anne ve Çocuk Sağllğg 1, 7-8.

${ }^{30}$ Semiz, İnsan Anatomisi ve Fizyolojisi, 167-168; MEB, Üreme Sistemi, 16-17; MEB, Anne ve Çocuk Să̆l̆ğ $1,7$.

${ }^{31}$ Semiz, Insan Anatomisi ve Fizyolojisi, 168.
} 
edilmeyip, ayrıca değerlendirilmesi gerekmektedir. Makalenin bu bölümünde, kadın iç üreme organlarının nakli İslâm hukuku açısından değerlendirilecektir.

\section{Fallop Tüplerinin Nakli}

Yukarıda açıklandığı üzere fallop tüpleri (tuba uterina), yumurta ile spermin buluşup döllenmenin meydana geldiği organdır. Tüplerde döllenen yumurta (zigot), buradan rahme intikal ederek oraya yerleşir. Kadının hamile kalabilmesi için tüplerin açık olması gerekir. Tüplerden birinin açık olması durumunda kadının doğal yolla hamile kalma ihtimali, az olmakla birlikte yine de bulunmaktadır. İki tüpün de tıkalı olması durumunda, doğal yolla gebelik ihtimali bulunmamaktadır. Tüplerin tıkalı olduğu bazı durumlarda, cerrahi müdahale ile tüpler açılabilmektedir. Fakat bazı durumlarda tüplerin cerrahi müdahale ile alınması gerekmektedir. Tüplerin tıkalı olması veya alınması durumunda tüp bebek yöntemiyle eşler çocuk sahibi olabilmektedir. Tüpler tıkalı olduğu için tüp bebek uygulamasında, uygulamadan önce tüplerin alınması tavsiye edilmektedir. ${ }^{32}$

Fallop tüpleri tıkalı olan veya tüpleri bulunmayan kadın, tüp bebek uygulamasıyla çocuk sahibi olabileceği için, tüp nakli, organ nakli çalışmaları arasında yer almamaktadır. Fallop tüplerinin nakliyle ilgili çalışma 1946 yılında başlamakla birlikte, ilk denemelerde başarılı olmamas1, zahmetli bir ameliyat olması, ameliyatta ve sonrasında hem donör hem de alıcı açısından risklerin bulunması; buna karş11ık tüp bebek uygulamalarının başarılı ve kolay olması sebebiyle bu çalışmalara devam edilmemiştir. ${ }^{33}$

Fallop tüpü nakli uygulanmamakla birlikte, yapılabilmesi imkân dâhilindedir. Bu sebeple tüplerin naklinin hükmü burada değerlendirilecektir. Üreme organlarının nakli konusu 23-26 Ekim 1989 tarihinde Kuveyt'te düzenlenen 5. Tıbbî F1kıh Konseyinde ve İslâm F1kıh Akademisi'nin 14-20 Mart 1990 tarihlerinde Cidde'de düzenlenen altıncı dönem toplantısında ele alınmıştır. Fakat bu toplantılarda alınan kararlarda, üreme organlarının nakli

\footnotetext{
32 Özlem Moraloğlu Tekin, Eylem Ünlübilgin, "Yardımcı Üreme Tekniklerinde Tubal Cerrahi”, Türk Üreme Tlbbl ve Cerrâhisi Dergisi, http://www.tjrms.org/current-issue/getpdf/30/148092364901829.pdf, (10.02.2018); Tunç, Spontan Yoldan Ve Yardımcı Ureme Teknikleri İle Gebe Kalan Hastaların Maternal, Fetal ve Perinatal Özelliklerinin Karşılaştırılması, 8, 18-19; Bülent Tıraş, "Yumurtalık veya Tüplerin Alınması Ameliyatı", https://www.bulenttiras.com/yumurtalik-veyatuplerin-alinmasi-ameliyati, (10.02.2018); Seval Taşdemir, "Hidrosalpenks Nedir?", https://www.sabah.com.tr/yazarlar/seval-tasdemir/2015/03/21/hidrosalpenks-nedir $\quad$ (10.02.2018); "Tüplerin T1kal1 (Kapal1) Olması", http://www.centrumtupbebek.com/tuplerin-tikali-kapaliolmasi.html (10.02.2018); “Tüplerin Aç1lması”, http://www.centrumtupbebek.com/tuplerinacilmasi.html (10.02.2018)

33 Talat Ahmed el-Kasbî, "İmkâniyyetü Nakli'l-A'zâi't-Tenâsüliyye fî̀l-Mer'e”, Mecelletü'lMecma'i'l-Fıkhi'l-İslâmî, Cidde 1990, VI, 1978-1980.
} 
detaylandırılmayıp genel ilkeler ortaya konmuştur. Bu kararlarda, "cinsel organ dışında kalan ve genetik özellikleri taşımayan üreme organlarının naklinin, İslam Fıkıh Akademisi'nin dördüncü dönem toplantısında alınan bir numaralı kararında belirlenen ölçülere uyulmak kaydıyla, meşru zaruretler çerçevesinde caiz olduğu.” belirtilmektedir ${ }^{34}$.

Söz konusu kararlara göre, fallop tüpü naklinin caiz olduğu söylenebilir. Nitekim bu kararın alındığı İslâm Fıkıh Akademisinin altıncı dönem toplantısında Halid Reşîd el-Cemîlî tarafından sunulan tebliğde de, neslin karışmasına neden olmadığı için, fallop tüpleri naklinin caiz olduğu belirtilmektedir. ${ }^{35}$ Fakat organ naklinin caiz olması için bulunması gereken şartlar, sadece İslâm Fıkıh Akademisinin 4/1 sayılı kararında belirtilen hususlar değildir. Adı geçen akademinin hem dördüncü, hem de altıncı dönem toplantılarında sunulan tebliğlerde ve yapılan tartışmalarda gündeme gelen, fakat belki de müsellem kabul edildiği için karara yansımayan bazı kriterler daha bulunmaktadır. ${ }^{36}$ Onlardan birisi de, Diyanet İşleri Başkanlığı Din İşleri Yüksek Kurulunun 03/03/1980 tarih ve 396/13 sayılı kararında belirtilen zaruret halidir. Bu karara göre organ naklinin caiz olması için, diğer şartların yanında, hastanın hayatını veya hayatî bir uzvunu kurtarmak için bundan başka çare olmadığının, meslekî ehliyet ve dürüstlüğüne güvenilen bir tabip tarafindan tespit edilmesi gerekir. ${ }^{37}$

Hâlbuki fallop tüpleri tıkalı olan veya alınan kadının çocuk sahibi olabilmesi için, fallop tüpü nakli yapılması zorunlu değildir. Çünkü tüpleri bulunmayan kadın, tüp bebek uygulamasıyla anne olabilmektedir. Diğer taraftan tüplerin nakli için yapılacak ameliyatta, hem donör, hem de alıcı açısından riskler bulunmaktadır. Dolayısıyla fallop tüplerinin nakli caiz değildir.

\section{Yumurtalık (Ovarium) Nakli}

Kadının çocuk sahibi olması için gerekli olan yumurta hücreleri, daha kendisi dünyaya gelmeden yumurtalıklarında oluşur ve ergenlik döneminden itibaren, menopoz dönemine kadar her ay bir yumurta olgunlaşarak fallop tüplerine alınır. ${ }^{38}$ Kemoterapi ve radyoterapi infertiliteye

\footnotetext{
34 “"5. Tıbbî Fıkıh Konseyin Sonuç Bildirgesi ve Tavsiye Kararları”, Mecelletü'l-Mecma'i'l-Fıkhi'lİslâmî, Cidde 1990, VI, 2067; “İslâm F1kıh Akademisi'nin 6/8/59 Sayılı Kararı", Mecelletü'lMecma'i'l-Fıkhi'l-İslâmî, Cidde 1990, VI, 2155.

${ }^{35}$ Halid Reşîd el-Cemîlî, "Ahkâmu Nakli'l-Husyeteyni ve'l-Mübeyyidayni ve Ahkâmu Nakli A'dâi'lCenîni'n-Nâkısi'l-Hilkati fî'ş-Şerîati'l-İslâmiyye”, Mecelletü 'l-Mecma'i'l-Fıkhi'l-İslâmî, Cidde 1990, VI, 1996.

${ }^{36}$ Organ nakliyle ilgili tebliğ ve tatı̧malar için bk. Mecelletü'l-Mecma'i'l-Fıkhi'l-İslâmî, IV, 89-504; Mecelletü'l-Mecma'i'l-Fikhi'l-İslâmî, VI, 1985-2145.

37 “Organ Nakli”, https://kurul.diyanet.gov.tr/Karar-Mutalaa-Cevap/9669/organ-nakli (03.02.2018)

${ }^{38}$ Kemal Tekin, Ferit Saraçoğlu, "Overlerin Dondurularak Saklanması”, Kadın Doğum Dergisi, Ankara 2, (2004), 3/187; Semiz, Insan Anatomisi ve Fizyolojisi, 165-167; Milli Eğitim Bakanlığı, Üreme
} 


\section{Paçacı}

yol açtığı gibi, pek çok sistemik ve otoimmün hastalığın tedavisinden ve kemik iliği, kök hücre naklinden önce kullanılan ilaçlar ile jinekolojik cerrahi de infertiliteye sebep olmaktadır. ${ }^{39}$ Son zamanlarda tedavi yöntemlerinde meydana gelen gelişmeler neticesinde hastalıkların tedavisi mümkün hale gelmiş; kanser vb. hastalığa yakalanan kimselerin hayatta kalma süreleri çok artmıştır. Bunun tabii sonucu olarak da, söz konusu tedavileri alacak genç kadınlarda doğurganlığı korumak için çare arama ihtiyacı doğmuştur. Bu kapsamda embriyo, yumurta veya yumurtalıkların dondurularak saklanması, doğurganlığı koruma seçenekleri olarak ortaya çıkmıştır. Evli olmayan kadınlar ile yeterli sürenin olmaması gibi durumlarda yumurta veya yumurtalık dokusu, evli olan kadınlarda ise yumurtalık ve yumurtalık dokusunun yanında embriyo da dondurularak saklanmakta ve tedavisi tamamlandıktan sonra kendisine nakledilerek hamile kalma imkânı sağlanmaktadır. ${ }^{40}$ Uzun süre hayvanlar üzerinde yapılan deneylerden sonra, insanlarda da yumurtalık dondurulması konusunda başarı elde edilmeye başlanmıştır. İlk dondurulmuş yumurtalık nakli, 1999 yılında Kutluk Oktay tarafından gerçekleştirilmiştir. Dondurulmuş yumurtalık nakliyle, 2016 yılına kadar 60 hamilelik olgusu bildirilmiştir. ${ }^{41}$

Sistemi, Ankara 2012, 15, 27-28; Milli Eğitim Bakanlığı, Çocuk Gelişimi ve Eğitimi Anne ve Çocuk Să̆ğğ 1, Ankara 2012, 7-8.

${ }^{39}$ Esra Atabenli Erdemli, Esra Atabenli Erdemli, Ferda Topal, Sinan Özkavukçu, Sibel Serin Kılıçoğlu, Deniz Balc1, Ovaryum Dokusunun, Vitrifikasyon ve Yavaş Soğutma Teknikleriyle Korunurluğunun Histopatolojik Yönden Karşılaşstırllması, Ankara Üniversitesi Bilimsel Araştırma Projesi Kesin Raporu, Ankara 2011, http://acikarsiv.ankara.edu.tr/browse/6436/Microsoft\%20Word\%20\%20BAP\%20proje_raporu.pdf (01.03.2018)

40 Tekin, Ferit Saraçoğlu, "Overlerin Dondurularak Saklanması", 188; Saraçoğlu, "Overlerin Dondurularak Saklanması", 187; Erdemli, Ovaryum Dokusunun, Vitrifikasyon ve Yavaş Soğutma Teknikleriyle Korunurluğunun Histopatolojik Yönden Karşılaştırılması, http://acikarsiv.ankara.edu.tr/browse/6436/Microsoft\%20Word\%20-\%20BAP\%20proje_raporu.pdf (01.03.2018); Tunç, Spontan Yoldan Ve Yardımcı Üreme Teknikleri Ile Gebe Kalan Hastaların Maternal , Fetal ve Perinatal Özelliklerinin Karşılaştırılması, 21; "Kardeşler Arası Yumurtalık Nakli", https://www.turkcebilgi.org/saglik/genetik/kardesler-arasi-yumurtalik-nakli-414.html (27.03.2018); "Kardeşler Aras1 Yumurtalık Nakli", http://uzunyasam.blogspot.com.tr/2009/08/kardesler-arasyumurtalk-nakli.html (23.02.2018).

${ }^{41}$ Tekin ve Saraçoğlu, "Overlerin Dondurularak Saklanması", 3/187; Sinan Özkavukçu, "Ovaryum Kriyoprezervasyonunun Folikülogeneze Etkileri”, XII. Ulusal Histoloji ve Ebriyoloji Kongresi Kongre Program ve Özet Kitabl, Ankara 2014, 34; Soner Çelik, Ovaryum Kriyoprezervasyonu ve Transplantasyonu Sonrasında Folikül Kaybı Mekanizmalarında Rol Alan Baskılayıcı Moleküllerin Araştırılması, (Yayınlanmamış Yüksek Lisans Tezi), Antalya 2016, 2; Erkan Gümüş, Celal Kaloğlu, İsmail Sarı, Meral Yılmaz, "Vitrifikasyon Yöntemiyle Dondurulan ve Ototransplantasyonu Yapılan Fare Ovaryum Dokularında Vasküler Endotelyal Kaderin (Ve-Kaderin) Ekspresyonlarının İncelenmesi”, Türk Biyokimya Dergisi, (2016), c.41, www.turkbiyokimyadernegi.org.tr/TBDDergisi/TBD-Sivas-Biyokimya-Gunleri.pdf, $\quad$ (01.03.2018); Erdemli vd., Ovaryum Dokusunun, Vitrifikasyon ve Yavaş Soğutma Teknikleriyle Korunurluğunun Histopatolojik Yönden Karşılaştırılması, http://acikarsiv.ankara.edu.tr/browse/6436/Microsoft\%20Word\%20-\%20BAP\%20proje_raporu.pdf (01.03.2018) 
Bunun dışında, yumurtalık yetmezliği ve kadında hızlı düşük yumurtalık rezervi olması da infertilite sebeplerindendir. ${ }^{42} \mathrm{Bu}$ durumda başka bir kadının yumurta veya yumurtalık dokusunun nakli veya taşıyıcı annelik tedavi yöntemi olarak düşünülebilir. Yumurtalık veya yumurtalık dokusunun nakli henüz deneme aşamasındadır. İlk yumurtalık nakli 1974 yılında gerçekleştirilmiş, fakat vücut kabul etmemiştir. Çünkü yumurtalıklarda doğuştan gelen yumurta hücreleri donörün genetik özelliklerini taşıdığı için, nakledilen kadınla genetik uyumsuzluk bulunmaktadır. Bu sebeple yumurtalık nakli, ikiz kardeşler gibi aynı veya çok yakın genetik özelliğe sahip kişiler arasında yapılabilmektedir. ${ }^{43}$ İlk başarılı taze yumurtalık nakli ise 2005 yılında gerçekleştirilmiştir. ${ }^{44}$ 14-19 Mayıs 2008 tarihlerinde Antalya'da düzenlenen 6'ncı Ulusal Jinekoloji ve Obstetrik Kongresi'ne katılan ABD'li Prof. Dr. Sherman Silber, 11 kadına yumurtalık nakli yapıldığını, bunlardan 10'una ikizlerinden, birine ise kardeşinden yumurtalık dokusu alındığını ve bunlardan 8'inin gebelikle sonuçlandığını söylemiştir. ${ }^{45}$

$\mathrm{Bu}$ açıklamalardan da anlaşıldığı üzere, yumurtalık/yumurtalık dokusu nakli, ya kadının kendisinden alınıp dondurularak saklanan yumurtalık dokusunun tekrar kendisine nakledilmesi (ototranplantasyon), ya da başka bir kadından alınan yumurtalık dokusunun nakli (transplantasyon) şeklinde olabilmektedir. Bu iki yumurtalık naklinin hükmü, ayrı ayrı ele alınacaktır:

\section{Yumurtalık Ototranplantosyonunun Hükmü}

Kemoterapi, radyoterapi gibi infertiliteye sebep olan tedavilerden önce bu tedavileri alacak kadınların çocuk sahibi olabilmeleri için embriyo, yumurta veya yumurtalıkların dondurularak saklanması bir tedavi olarak uygulanabilmektedir. Bu tedavilerden önce kadından alınan yumurtalar dondurularak saklanmakta ve tedavisi tamamlandıktan sonra, eşinden alınan

\footnotetext{
${ }^{42}$ Aslan, Üniversite Hastanesine Başvuran Fertil ve Infertil Kadınların Yumurta Donasyonu Hakkındaki Düşünceleri, 2; Tunç, Spontan Yoldan Ve Yardımcı Üreme Teknikleri İle Gebe Kalan Hastaların Maternal , Fetal ve Perinatal Özelliklerinin Karşılaştırılması, 21.

${ }^{43}$ Talat Ahmed, "İmkâniyyetü Nakli'l-A'zâi't-Tenâsüliyye fî'l-Mer'e", Mecelletü'l-Mecma'i 'l-Fıkhi'lİslâmî, $\quad$ VI, 1978; "Kardeşler Arası Yumurtalık Nakli", https://www.turkcebilgi.org/saglik/genetik/kardesler-arasi-yumurtalik-nakli-414.html (27.03.2018); "Kardeşler Arası Yumurtalık Nakli", http://uzunyasam.blogspot.com.tr/2009/08/kardesler-arasyumurtalk-nakli.html (23.02.2018).

${ }^{44}$ Çetin ve Çetin, "Dünden Bugüne Yardımla Üreme Teknikleri”, 154.

45 "Tüp Bebek Güncel Haberler", http://www.cyprusivf.net/tup-bebek-guncel-haberler/ (27.03.2018); “Tüp Bebek Güncel Haberler”,http://www.zypernivf.com/tup-bebek-guncel-haberler/ (27.03.2018); "Yumurtalık ve Rahim Nakli Hayal Değil" https://www.saglikaktuel.com/haber/yumurtalik-ve-rahimnakli-hayal-degil-2593.htm, (27.03.2018); "Yumurtalı ve Rahim Nakli Hayal Değil", http://www.hurriyet.com.tr/kelebek/saglik/yumurtalik-ve-rahim-nakli-hayal-degil-8978150, (27.03.2018).
} 
sperm ile döllenerek ana rahmine yerleştirilmekte veya alınan yumurta eşinden alınan sperm ile döllendikten sonra dondurulmakta ve tedavi tamamlandıktan sonra ana rahmine yerleştirilmektedir. Üçüncü bir yöntem olarak da, bu tür tedaviden önce kadından yumurtalık dokusu alınıp dondurularak saklanmakta ve tedavisi tamamlandıktan sonra bu doku ya karın boşluğundaki yerine veya vücutta başka bir yere nakledilmektedir. Karın boşluğundaki yerine nakledilmesi durumunda tabii yolla hamilelik olabilmektedir. Vücutta başka bir yere nakledilmesinde ise, yumurta gelişimi sağlanarak tüp bebek uygulamasına başvurulmaktadır. ${ }^{46}$

Bu tedavi yöntemlerinden embriyo ve yumurtanın dondurularak saklanmasının hükmü, tüp bebek kapsamında değerlendirilebilir. Tüp bebek uygulaması ise caizdir. Nitekim İslâm Konferansı Örgütü bünyesinde bulunan İslâm F1kıh Akademisi'nce Amman'da düzenlenen üçüncü dönem toplantısında, döllenen yumurta ile spermin eşlere ait olması kaydıyla tüp bebek uygulamasında sakınca olmadığına karar verilmiştir. ${ }^{47}$

Kadından alınan yumurtalık dokusunun dondurularak saklanması ve daha sonra kendisine nakledilmesi ise organ nakli kapsamına girmektedir. Burada nakledilen doku zaten kadının kendisine ait olduğu için, neslin karışması söz konusu değildir. Buna göre organ naklinde aranan genel şartlara riayet edilmesi kaydıyla bunun caiz olduğu söylenebilir. Nitekim İslâm F1kıh Akademisi'nin 14-20 Mart 1990 tarihlerinde Cidde'de düzenlenen altıncı dönem toplantısında, "genetik özellikleri taşımayan üreme organlarının naklinin, meşru zaruretler çerçevesinde caiz olduğu." karara bağlanmıştır. ${ }^{48}$

\section{Yumurtalık Transplantosyonunun Hükmü ve Sonuçları}

Kanser veya erken menopoz sebebiyle kısır olan kadınların çocuk sahibi olabilmesi için uygulanacak tedavi yöntemleri arasında başkasına ait embriyo, yumurta veya yumurtalık dokusu nakli yer almaktadır. Bunlardan başkasına ait embriyo ve yumurta nakli, taşıyıcı annelik kapsamında değerlendirilebilir. Taşıyıcı annelik ise ayrı bir çalışma konusu olduğu için burada ele alınmayacaktır. ${ }^{49}$ Yumurtalık transplantasyonu ise, kadın üreme organı nakli kapsamında

\footnotetext{
${ }^{46}$ Tekin ve Saraçoğlu, "Overlerin Dondurularak Saklanması”, 3/187; ${ }^{46}$ Atabenli Erdemli, vd., Ovaryum Dokusunun, Vitrifikasyon ve Yavaş Soğutma Teknikleriyle Korunurluğunun Histopatolojik Yönden Karşılaştırılması, $\quad$ http://acikarsiv.ankara.edu.tr/browse/6436/Microsoft\%20Word\%20\%20BAP\%20proje raporu.pdf (01.03.2018)

47 “4 sayıl1 Tüp Bebek Kararı”, Mecelletü'l-Mecma'i'l-Fikhi'l-İslâmî, yy. 1987, III, 515-516.

48 “İslâm Fıkılh Akademisi'nin 6/8/59 Sayılı Kararı", Mecelletü'l-Mecma 'i'l-Fılkhi'l-İslâmî, Cidde 1990, VI, 2155.

49 Taşıyıcı annelik konusunda geniş bilgi için bk. Ayşe Şimşek, "İslâm Hukuku Açısından Taşıyıcı Annelikte Meşruiyet Tartı̧̧maları”, İslâm Hukuku Araştırmaları Dergisi, Konya (2014), 24/241-266; Ülfet Görgülü, "Taşıyıcı Annelik -Fıkhi Bir Bakış-", İslâm Hukuku Araşstırmaları Dergisi, Konya (2010), 15/197-208.
} 
olup, İslâm hukuku açısından burada değerlendirilecektir.

Yumurtalık nakli henüz deneme aşamasında olup, henüz ikiz kardeş veya kardeşler gibi aynı veya çok yakın genetik özelliğe sahip kişiler arasında yapılabilmektedir. ${ }^{50}$ Ülkemiz mevzuatı açısından yumurtalık nakli diğer organ nakilleri gibi kabul edilmektedir. Nitekim Sağlık Bakanlığı Tedavi Hizmetleri Genel Müdür Yardımcısı Doktor Bekir Keskinkılıç, veren ve alanın razı olması kaydıyla yumurtalık dokusu naklinin önünde yasal engel olmadığını açıklamıştır. $^{51}$

Hâlbuki İslâm hukukunda yumurtalık nakli, diğer organ nakilleri gibi değildir. Yumurtalık naklinin hükmünün diğer organ nakillerinden ayrı değerlendirilmesi gerekir. Ayrıca fiili olarak yumurtalık nakli gerçekleşirse, bunun doğuracağı hukuki sonuçlar da ele alınmalıdır.

\section{Yumurtalık naklinin hükmü}

Daha önce de açıklandığı üzere, ergenlik döneminden itibaren, menopoz dönemine kadar olgunlaşarak fallop tüplerine alınacak yumurta hücreleri, doğuştan yumurtalıklarda gelmektedir. ${ }^{52}$ Buna göre bir kadından başka birine yumurtalık dokusu nakledildiğinde, aynı zamanda ona ait yumurtalar da nakledilmektedir. Bunun sonucu olarak da, kişi nikâhlı eşine ait olmayan yumurtadan çocuk sahibi olmaktadır. Dolayısıyla yumurtalık dokusu nakli, neslin karışmasına sebep olmaktadır. Bu ise caiz değildir. İslâm Fıkıh Akademisi’nin 14-20 Mart 1990 tarihlerinde Cidde'de düzenlenen altıncı dönem toplantısında da, genetik özellikleri taşıyan üreme organlarının naklinin caiz olmadığı karara bağlanmıştır..$^{53}$

Burada, -taşıyıcı annelikte olduğu gibi ${ }^{54}$ - eşlerin birinden alınan yumurtalık dokusunun,

\footnotetext{
${ }^{50}$ Talat Ahmed, “İmkâniyyetü Nakli'l-A'zâi't-Tenâsüliyye fî'l-Mer'e”, Mecelletü'l-Mecma'i 'l-Fıkhi'lİslâmî, $\quad$ VI, 1978; "Kardeşler Arası Yumurtalık Nakli", https://www.turkcebilgi.org/saglik/genetik/kardesler-arasi-yumurtalik-nakli-414.html (27.03.2018); "Kardeşler Arası Yumurtalık Nakli", http://uzunyasam.blogspot.com.tr/2009/08/kardesler-arasyumurtalk-nakli.html (23.02.2018).

51 "Kardeşler Arası Yumurtalık Nakli”, https://www.turkcebilgi.org/saglik/genetik/kardesler-arasiyumurtalik-nakli-414.html (27.03.2018); "Kardeşler Aras1 Yumurtalık Nakli", http://uzunyasam.blogspot.com.tr/2009/08/kardesler-aras-yumurtalk-nakli.html (23.02.2018).

${ }^{52}$ Kemal Tekin, Ferit Saraçoğlu, “Overlerin Dondurularak Saklanması”, Kadın Doğum Dergisi, Ankara 2, (2004), 3/187; Semiz, Insan Anatomisi ve Fizyolojisi, 165-167; Milli Eğitim Bakanlığ1, Üreme Sistemi, Ankara 2012, 15, 27-28; Milli Eğitim Bakanlığı, Çocuk Gelişimi ve Eğitimi Anne ve Çocuk Să̆ll̆̆ l, Ankara 2012, 7-8.

53 “İslâm Fıkıh Akademisi'nin 6/8/59 Sayılı Kararı", Mecelletü'l-Mecma 'i'l-Fılkhi'l-İslâmî, Cidde 1990, VI, 2155.

${ }^{54}$ Abdurrahman el-Bessâm, "Etfâlu'l-Enâbîb", Mecelletü'l-Mecma 'i'l-Fikhi'l-İslâmî, Cidde 1986, II, 266; Muhammed Ali el-Bâr, "et-Telkîhu's-Sinâ'î ve Etfâlu'l-Enâbîb”, Mecelletü'l-Mecma'i'l-Fikhi'lİslâmî, Cidde 1986, II, 282-283; Rabitatü'l-Alemi'l-İslâmî bünyesinde bulunan İslâm Fıkıh
} 
diğer eşe nakledilmesi önerilebilir. Fakat bunda da iki problem söz konusudur. Yumurtalık nakli, ikiz kardeş veya kardeşler gibi aynı veya çok yakın genetik özelliğe sahip kişiler arasında yapılabilmektedir. ${ }^{55}$ Hâlbuki bu kimselerin aynı kişinin nikâhında birlikte bulunması helal değildir ${ }^{56}$. Diğer taraftan, yumurtalık nakli yapılan kadının kocasının ölmesi veya ondan ayrılması her zaman ihtimal dâhilindedir. Bu durumda, yumurtalıklarında bulunan yumurta hücreleri, önceki eşinin karısına aittir. Daha sonra evlenir ve yeni kocasından hamile kalırsa, bu eşinin spermi ve eski eşinin karısının yumurtasıyla hamile kalmış olacaktır. Bu ise, neslin karışmasına sebep olduğu için, haramdır. Dolayısıyla, eşlerin birinden alınan yumurtalık dokusunun, diğer eşe nakledilmesi de caiz değildir.

\section{Yumurtalık Naklinin Sonuçları}

Bir kadından alınan yumurtalık dokusunun, başka bir kadına nakledilmesi İslâm hukuku açısından caiz değildir. Yumurtalık nakli caiz olmamasına rağmen, bunu yapan kişiler çıkabilecektir. $\mathrm{Bu}$ durumda çocuğun nesebi, sıhriyet hısımlığı gibi problemler ortaya çıkmaktadır. Makalenin bu kısmında bu konular değerlendirilecektir.

Daha önce de belirtildiği gibi, yumurtalık dokusu naklinde, yumurta hücreleri doku ile birlikte gelmektedir; dolayısıyla yumurtalar donöre aittir ve onun genetik özelliklerini taşımaktadır. ${ }^{57}$ Buna göre yumurtalık naklinden sonra kadın hamile kalarak çocuk dünyaya getirse; DNA testinde çocuğun annesi dokunun alındığg kadın çıkacaktır. Bu durumda çocuğun annesi olarak, kendisini doğuran kadın mı, yoksa yumurtanın sahibi olan genetik anne mi kabul edilmelidir.

Türk Medenî Kanununa göre, çocuğun annesi, onu doğuran kadındır. ${ }^{58} \mathrm{Bu}$ hususta belirleyici unsur, çocuğu dünyaya getirmektir. Hukukçular arasında anneye, çocuğun nesebini reddetme hakkının verilip verilmeyeceği tartışmalıdır. Hukukçuların çoğunluğu, annenin

\footnotetext{
Akademisi'nin “et-Telkîhu's-Sinâ'î ve Etfâlu'l-Enâbîb” kararı, Mecelletü'l-Mecma 'i'l-Fıkhi'l-İslâmî, Cidde 1986, II, 336.

${ }^{55}$ Talat Ahmed, "İmkâniyyetü Nakli'l-A'zâi't-Tenâsüliyye fî'l-Mer'e”, Mecelletü'l-Mecma'i'l-Fikhi'lİslâmî, $\quad$ VI, 1978 ; $\quad$ Kardeşler Arası Yumurtalık Nakli", https://www.turkcebilgi.org/saglik/genetik/kardesler-arasi-yumurtalik-nakli-414.html (27.03.2018); "Kardeşler Arası Yumurtalık Nakli”, http://uzunyasam.blogspot.com.tr/2009/08/kardesler-arasyumurtalk-nakli.html (23.02.2018).

${ }^{56}$ Nisa $4 / 23$.

${ }^{57}$ Kemal Tekin, Ferit Saraçoğlu, "Overlerin Dondurularak Saklanması”, Kadın Doğum Dergisi, Ankara 2, (2004), 3/187; Semiz, Insan Anatomisi ve Fizyolojisi, 165-167; Milli Eğitim Bakanlı̆̆1, Üreme Sistemi, Ankara 2012, 15, 27-28; Milli Eğitim Bakanlığı, Çocuk Gelişimi ve Eğitimi Anne ve Çocuk Sağlı̆̆ 1, Ankara 2012, 7-8.

${ }^{58}$ Türk Medenî Kanunu, Madde 282: "Çocuk ile ana arasında soybağı doğumla kurulur."
} 
çocuğun nesebini reddetme hakkının olmadığı görüşündedir. Türk Medenî Kanunda da anneye, nesebi reddetme hakkı verilmemiştir. ${ }^{59}$ Yumurtalık dokusu nakledilen kadın, evlilik birliği içinde çocuk dünyaya getirirse, Medenî Kanunun 285. maddesine göre, çocuğun annesi doğuran kadın, babası da kadının kocasıdır. Buna göre, çocuğun nesebinin, yumurtalık dokusu alınan kadına bağlanması mümkün değildir. ${ }^{60}$

İslâm hukukuna göre de çocuğun annesi, kendisini dünyaya getiren kadındır. Nitekim Kur'ân'da, “Onların anaları, ancak kendilerini doğuran kadınlardır." buyrulmaktadır. ${ }^{61}$ Buna göre çocukla annesi arasında nesep bağı doğumla kurulur ve kadının çocuğu reddetmesi de mümkün değildir. ${ }^{62}$ İslâm hukukunda çocuğun babasıyla soy bağının kurulmasının sebepleri, sahih evlilik, fasit evlilik ve evlilik şüphesiyle cinsel ilişkidir. ${ }^{63}$ Evlilik birliği içinde dünyaya gelen çocuğun nesebi, babasından sabit olur. Nikâh akdinden altı ay sonra ve evliliğin sona ermesinden itibaren hamileliğin en uzun süresi ${ }^{64}$ içinde dünyaya gelen çocuğun babası, onu dünyaya getiren kadının eşidir. Nitekim Hz. Peygamber (s.a.s.), “Çocuk, anneyle birlikte olması meşru olan kişiye aittir; zina edene ise mahrumiyet vardır." buyurmaktadır ${ }^{65}$. Çocuğun nesebinin babasından sabit olması için, doğuran kadının eşinin baba olabilecek çağda olması ve cumhura göre fiilen bir araya gelip birlikte olmalarının mümkün olması gerekir ${ }^{66}$. Hanefilere

\footnotetext{
${ }^{59}$ İsmail Aytaç, "Yardımcı Üreme Tekniklerinin Nesep Hukuku Açısından İncelenmesi” Adalet Dergisi, sy.11, http://www.yayin.adalet.gov.tr/adaletdergisi/11.sayi/5ismail.pdf (21.04.2018).

${ }^{60}$ İsmail Aytaç, "Yardımcı Üreme Tekniklerinin Nesep Hukuku Açısından İncelenmesi”" Adalet Dergisi, sy.11, http://www.yayin.adalet.gov.tr/adaletdergisi/11.sayi/5ismail.pdf (21.04.2018).

${ }^{61}$ Mücadele 58/2.

${ }^{62}$ Alâuddîn el-Kâsânî, Bedâi'u's-Sanâi' fì Tertîbi'ş-Şerâi', Dâru'l-Kitâbi'l-Arabî, Beyrut 1982, VI, 255; Hayrettin Karaman, Mukayeseli İslâm Hukuku, Nesil Yayınları, İstanbul 1991, I, 335.

${ }^{63}$ Vehbe Zuhaylî, el-Fıkhu'l-İslâmî ve Edilletuhu, Daru'l-Fikr, Dimeşk 1985, VII, 681; Karaman, Mukayeseli İslâm Hukuku, I, 335.

${ }^{64}$ Hamileliğin en uzun süresi konusunda İslâm bilginleri farklı görüşler ortaya koymuştur. Bunların en meşhurları şöyledir: Hanefilere göre bu süre iki y1l (Kâsânî, Bedâi'u's-Sanâi', III, 211; İbn Hümâm, Fethu'l-Kadîr, IV, 317), Şâfiîlere ve Hanbelîlere göre dört y1l (Şirbînî, Muğni'l-Muhtâc, III, 390; Muvaffukuddin Ebû Muhammed Abdullah b. Ahmed İbn Kudâme, el-Muğnî, Dâru'l-Kitâbi'l-Arabî, Beyrut 1983, VI, 475. IX, 97), Mâlikîlere göre beş yıldır. Bazı Mâlikîlerin, bu süreyi yedi yıl kabul ettiği de nakledilmektedir (İbn Rüşd, Bidâyetü'l-Müctehid, II, 358). Buna karş1lık Maliki bilgin Muhammed b. el-Hakem hamileliğin en uzun süresinin bir y1l olduğunu (İbn Rüşd, Bidâyetü 'l-Müctehid, II, 358); İbn Hazm ise, dokuz ay olduğunu söylemektedir (Muhallâ, X, 317). Hamileliğin en uzun süresiyle ilgili bu görüşler, daha çok kendi dönemlerindeki tıbbî bilgi, tecrübe ve anlayışlara göre şekillenmiştir. Günümüzde artık ceninin anne karnındaki bütün aşamaları, rahimde kalma ve yaşayabilme imkânı bilinmektedir. Bu sebeple, günümüz tıbbının verilerine göre hareket etmek uygun olur.

${ }^{65}$ Buhârî, Buyû', 3, Ferâiz, 17; Müslim, Radâ‘, 36; Tirmizî, Radâ‘, 8; Ebû Dâvûd, Talâk, 34; Nesâî, Talâk, 48.

${ }^{66}$ Ebû İshâk eş-Şîâyzî, el-Mühezzeb, Daru'l-Kalem, Dımeşk, 1996, IV, 443-444; İbn Rüşs, Bidâyetü'lMüctehid, II, 358; İbn Kudâme, el-Muğnî, XI, 167-168; Zuhaylî, el-Fıkhu'l-İslâmî ve Edilletuhu, VII, 682-683; Fahruddîn Osman b. Ali ez-Zeylaî, Tebyînü'l-Hakâik Şerhu Kenzi'd-Dekâik, Matbaatu'lKübrâ'l-Emîriyye, Bulak 1314, III, 39.
} 


\section{Paçacı}

göre, akdin bulunması yeterlidir, fiilen birlikte olmalarının mümkün olması şart değildir. ${ }^{67}$

Yumurtalık nakli yapılan kadının dünyaya getirdiği çocuğun nesebi, bu bilgiler doğrultusunda şöyle değerlendirilebilir: Yumurtalık naklinde, yumurtaların donöre ait olması sebebiyle, çocuğun annesi yumurtanın sahibi olarak kabul edilirse, çocuk nikâh dışı doğmuş olacaktır. Nikâh dışı dünyaya gelen çocuğun nesebi ise sabit olmaz. Hâlbuki çocuğun nikâhlı eşlerden dünyaya gelmesi, nesebinin sabit olması çocuk için çok önemlidir. Çocuğun gayrimeşru dünyaya gelmesi, nesebinin sabit olmaması, çocuk açısından son derece kendisini inciten ve acı veren bir durumdur. Bundan dolayı çocuğun babasız kalmaması, nesebinin belli olup utanç duymaması için, çocuğun nesebi kendini dünyaya getiren kadının kocasından kabul edilmiştir. ${ }^{68}$ Böyle bir çocuğun nesebinin reddedilmesi, ancak li‘ân ile mümkündür. ${ }^{69}$ Çocuğun babasının tespitinde nikâh, kuvvetli bir karine olarak görülmüş, bu konuda şüpheler dikkate alınmayıp karşısında delilin terk edileceği kabul edilmiştir. ${ }^{70}$ Nitekim bir bedevî $\mathrm{Hz}$. Peygamber'e (s.a.s.) gelerek, eşinin doğurduğu çocuğun nesebinin kendine ait olmadığını ima ederek; "Ya Rasûlallâh! Eşim siyah derili bir çocuk dünyaya getirdi?" diye sorar. Hz. Peygamber (s.a.s.) ona, "Senin develerin var mı?” diye karşılık verir. Adam, "Evet” deyince, “Onlar hangi renk?” diye sorar. O, "Kızıl."” cevabını verince, bu defa "Aralarında boz renkli var mı?” diye sorar. Adam “Aralarında boz renkli olan var.” deyince, Hz. Peygamber (s.a.s.), "Peki bunun nereden geldiğini düşünüyorsun?" diye sorar. Adam, "Soyunda kendisine çektiği bir deve vardır." diye cevap verince, "Belki bu çocuk da, soyunda bulunan birine çekmiş olabilir." buyurur. ${ }^{71}$ Çocuğun nesebinin tespitinde nikâh asıl olup, şüpheye itibar edilmediği için Hanefi fıkhında, biri doğuda, diğeri batıda bulunan erkek ile kadın evlense ve altı ay sonra kadın bir çocuk dünyaya getirse nesebinin babasından sabit olduğu benimsenmiştir² . Hatta Kâsânî (ö. 587/1191), eşler çocuğun, belli biriyle yapılan zinadan dünyaya geldiğini kabul etseler bile,

\footnotetext{
${ }^{67}$ Kâsânî, Bedâi'u's-Sanâi', III, 212; Zeylaî, Tebyînü'l-Hakâik, III, 38-39.

${ }^{68}$ İbn Kudâme, el-Muğnî, VI, 393; Muhammed b. Salih b. Muhammed el-Useymîn, eş-Şerhu'l-Mümti' alâ Zâdi'l-Müstekni', Dâru İbni'l-Cevzî, yy., 1422, XIII, 308; Karaman, Mukayeseli İslâm Hukuku, I, 278.

${ }^{69}$ Muhammed b. İdrîs eş-Şâfîi, el-Ümm, Dâru'l-Ma'rife, Beyrut 1393, V, 130; Şemsü’l-eimme Ebû Bekr Muhammed b. Ebî Sehl es-Serahsî, Kitâbu'l-Mebsût, Dâru'l-Mâ'rife, Beyrut ty., XVII, 100; Kâsânî, Bedâi'u's-Sanâi', VI, 243, 255; Ebû'l-Hasen Ali b. Sa'îd er-Recrâcî, Menâhicu't-Tahsîl ve Netâicu Letâifi 't-Te'vîl fí Şerhi'l-Müdevveneti ve Halli Müşkilâtihâ, Dâru'bni Hazm, Beyrût 2007, V, 372; İbn Kudâme, el-Muğnî, IX, 27.

70 İbn Kudâme, el-Muğnî, VI, 297; Mustafa es-Suyûtî er-Ruhaybânî, Metâlibu Üli'n-Nühâ fỉ Şerhi Gayeti'l-Müntehâ, el-Mektebü'l-İslâmî, Dimeşk 1961, V, 555.

${ }^{71}$ Buhârî, "Muhâribîn", 27, "İ'tisâm", 12; Müslim, "Liân", 18, 20.

${ }^{72}$ Kâsânî, Bedâi'u's-Sanâi', II, 331-332; Zeylaî, Tebyînü'l-Hakâik, III, 39; Muhammed Emin b. Ömer İbn Âbidîn ed-Dımeşkî, Hâsşiyetü Reddi'l-Muhtâr alâ'd-Dürrî'l-Muhtâr Şerhi Tenvîri' 'l-Ebsârr, İstanbul 1984, III, 118, 413.
} 
nesebinin kocadan sabit olacağını söylemiştir ${ }^{73}$.

Buna göre, yumurtalık naklinden sonra dünyaya gelen çocuğun nesebinin, kendisini doğuran anne ve eşinden sabit olması uygundur. Her ne kadar yumurtaları oluşturan kök hücreler yumurtalıklarla birlikte nakledilmiş olsa da, yumurta hücreleri yumurtalık nakledilen kadında ve ondan aldığı besinle olgunlaşmıştır. Dolayısıyla yumurtanın oluşum ve olgunlaşmasında iki kadının da katkısı bulunmaktadır. Ayrıca yumurta döllendikten sonra cenin, anne karnında gelişmiştir. Bu durumda iki kadını da anne kabul etmek, çifte anneliğe veya ikiye bölünmüş anneliğe götürecektir. $\mathrm{Bu}$ ise, ailenin ve çocuğun mutluluğuna gölge düşürecektir. Bunun için insanın hukuken tek bir annesi olması gerekir. Aksine üretilen çözümler, çözümlenmesi güç daha büyük problemlerin doğmasına neden olur. ${ }^{74}$ Ayrıca babasından nesebinin sabit olması için de, çocuğun doğuran anneye ait olduğunu kabul etmek gerekir. Sonuç olarak, çocuğun yararı gözetilerek, yumurtalık naklinde çocuğun annesini kendini doğuran kadın ve babasını da onun eşi kabul etmek uygun olur.

Bununla birlikte, çocuğun dünyaya geldiği yumurtanın asıl sahibinin, kendisinden yumurtalık alınan kadın olduğu gerçeği de önümüzde durmaktadır. Bunun hukukî sonucu ise, o kadınla çocuk arasında evlilik engelinin meydana gelmesidir. Buna göre, yumurtalık naklinden dünyaya gelen çocuk, kendisinden yumurtalık alınan kadının kendisiyle, onun usulü, furûu, anne ve babasının furûu, dede ve ninelerinin çocuklarıyla evlenemez. Nitekim Hz. Peygamber (s.a.s.) zamanında meydana gelen şu olay da, yumurtalık alınan kadın ile çocuk arasında evlilik engelinin olduğunu göstermektedir: Sa ‘d b. Ebî Vakkas ile Abd b. Zem‘a, bir çocuk hakkında davalaşırlar. Sa 'd, çocuğun kardeşi Utbe'ye benzerliğini de göstererek, onun kardeşinin çocuğu olduğunu, kardeşinin kendisine, bu çocuğa sahip çıkmasını vasiyet ettiğini söyler. Hz. Peygamber'in (s.a.s.) kayın biraderi olan Abd b. Zem‘a da, çocuğun annesinin, kendi babasının cariyesi olduğu için, çocuğun babasıyla o kadının meşru birlikteliklerinden dünyaya geldiğini, dolayısıyla kardeşi olduğunu iddia eder. Rasûlullâh (s.a.s.) çocuğun simasının Utbe'ye çok benzediğini görür, fakat “Ey Abd, bu çocuk senin kardeşindir. Çünkü çocuk, anneyle birlikte olması meşru olan kişiye aittir; zina edene ise mahrumiyet vardır." buyurur. Hadisin devamında ise, çocuğun hukuken kayınbiraderinin kardeşi olduğuna hükmetmiş olmasına rağmen, çocuk Utbe'ye çok benzediği için, eşine, “Ey Sevde b. Zem 'a,

\footnotetext{
${ }^{73}$ Kâsânî, Bedâi' 'u's-Sanâi', VI, 243.

${ }^{74}$ İsmail Aytaç, "Yardımcı Üreme Tekniklerinin Nesep Hukuku Açısından İncelemesi”, Adalet Dergisi, Ankara 11 (2002), http://www.yayin.adalet.gov.tr/adaletdergisi/11.sayi/5ismail.pdf (21.04.2018).
} 
sen de bu çocuğa karşı örtün" der. ${ }^{75}$ Görüldüğü gibi Hz. Peygamber (s.a.s.), hukuken çocuğun babasının kayınpederi olduğuna hükmetmekle birlikte, evlilik engelleri bakımından gerçek babasını dikkate almıştır. Bunun için Hanefîler, zina ile nesep sabit olmasa da, evlilik engeli doğacağını kabul etmiştir. ${ }^{76}$ Burada da, yumurtanın asıl sahibi, kendisinden yumurtalık alınan kadın olduğu için, evlilik engelinin meydana geleceği kabul edilmelidir.

\section{Rahim (Uterus) Nakli}

Bazı kadınlarda yumurtalık fonksiyonları yeterli olmakla birlikte, uterus faktörlü infertilite (UFI), başka bir deyişle rahimden kaynaklanan kısırlık sebebiyle, çocuk sahibi olamamaktadır. Böyle kadınların çocuk sahibi olabilmeleri için, bazı ülkelerde taşıyıcı annelik yasal kabul edilmiştir. Fakat ülkemizin de içinde bulunduğu diğer ülkelerde ise, taşıyıcı annelik yasal değildir. -Taşıyıcı annelik, ayrı bir çalışmanın konusu olduğu için, burada hükmü irdelenmeyecektir.- Taşıyıcı anneliğin yasal olmadığı ülkelerde, uterus nakli, bu kadınların çocuk sahibi olmalarını sağlayabilecek bir çözüm olarak görülebilir. 1960'lı yıllardan itibaren hayvanlar üzerinde rahim nakli çalışmaları yapılmaktadır. İnsandan insana rahim nakli, ilk olarak 2000 yılında Suudi Arabistan'da gerçekleştirilmiştir. Fakat nakil işleminden 99 gün sonra, doku ölümü meydana geldiği için çıkarılmak zorunda kalınmıştır. Dünyada insandan insana yapılan ikinci rahim nakli ise, 2011 yılında Akdeniz Üniversitesi Tıp fakültesinde gerçekleştirilmiştir. 2013 yılı Nisan ayında, dondurulmuş embriyoların nakliyle kadın hamile kalmış, fakat gebeliğin 5. haftasında düşükle sonuçlanmıştır. 2012 yılında İsviçre'de dokuz kadına, canlılardan alınan uteruslar nakledilmiştir. Bu çalışmada donörlerin beşi, nakledilen kadınların annesidir. Vakaların ikisinde, nakledilen rahim geri alınmak zorunda kılınmıştır. Diğer yedi vakada ise, düzenli adet kanaması izlenmiştir. Ve bu kadınlardan biri, 2014 yılı Ekim ayında sağlıklı doğum gerçekleştirmiştir. ${ }^{77}$

Daha önce de açıklandığı üzere, tüplerde yumurtanın döllenmesiyle meydana gelen zigot,

\footnotetext{
${ }^{75}$ Bk. Buhârî, "Buyû‘", 3, 100, "Husûmât", 5; Müslim, "Radâ'”, 36.

${ }^{76}$ Kâsânî, Bedâi 'u's-Sanâi', II, 262; İbn Hümâm, Fethü 'l-Kadîr, III, 199.

${ }^{77}$ Ruşen Öztürk, Ümran Sevil, "Uterus Transplantasyonu ve Etik”, Gümüşhane Üniversitesi Sağllk Bilimleri Dergisi, 4/538-539; Tuğba Uğurlu, Antioksidanlartn Uterus Transplantasyonunda Angiogenezise Etkileri, (Yayınlanmamış Yüksek Lisans Tezi) Ankara 2017, 25-27; İlkay Başer Demircan, Histidin-Triptofan-Ketoglutarat (Htk) Çözeltisine Eklenen Acetyl-L-Carnitin'in Donör Uterus'daki Koruyucu Etkilerinin Araşstıılması, (Yayınlanmamış Yüksek Lisans Tezi) Ankara 2012, $108-110$
} 
buradan rahme geçerek yerleşmekte ve yaklaşık kırk hafta burada kalmaktadır. ${ }^{78} \mathrm{Bu}$ dönemde rahmin fonksiyonu, embriyonun endometriuma yerleşmesini sağlayıp, onu korumak; beslenmesini ve oksijenini sağlamak, ondan karbondioksit ve atıkları almak ve hamileliğin sonunda da orta tabakadaki düz kas liflerinin kasılmasıyla doğuma yardımcı olmaktır. ${ }^{79}$ Uterus transplantasyonunda nakledilen rahim, kendisine nakledilen kadından çıkarılan rahmin yerini alarak, yukarıda sayılan fonksiyonları icra etmektedir. Bu durumda rahim, kendisine nakledilen kadının bir organı olmakta ve yukarıda açıklanan görevi yerine getirirken, donörün genetik özelliğini doğacak çocuğa taşımamaktadır.

Buna göre rahim nakli, üreme organları dışındaki organların nakliyle aynı hükümdedir. Dolayısıyla vefat eden ve menopoza giren kadınlardan, kendileri veya velilerinin izniyle, karşılığında bir ücret alınmaksızın uterus faktörlü infertiliteli kadınlara rahim nakli caizdir. Nitekim üreme organlarının nakli konusu ele alınan 5. Tıbbî Fıkıh Konseyinde ve İslâm Fıkıh Akademisi'nin 14-20 Mart 1990 tarihlerinde Cidde'de düzenlenen altıncı dönem toplantısında, “cinsel organ dışında kalan ve genetik özellikleri taşımayan üreme organlarının naklinin, İslam F1kıh Akademisi'nin dördüncü dönem toplantısında alınan bir numaralı kararında belirlenen ölçülere uyulmak kaydıyla, meşru zaruretler çerçevesinde caiz olduğu” karara bağlanmıştır ${ }^{80}$.

\section{SONUÇ}

Her canlı gibi insan da, çocuk sahibi olup neslini devam ettirmeyi ister. Bununla birlikte her evli çift çocuk sahibi olamamaktadır. Üreme çağındaki çiftlerin bir yıl boyunca çocuk sahibi olmayı istemelerine rağmen gebeliğin oluşmaması veya gebeliği sürdürememe durumu, tıbben "infertilite" olarak adlandırılmaktadır. Tabii yollarla çocuk sahibi olamayan çiftlerin pek çoğu, geliştirilen yardımcı üreme yöntemleriyle artık çocuk sahibi olabilmektedir. Bu yöntemler arasında, üreme organlarının nakli de yer almaktadır. Bu çerçeveden olarak ilk başarılı taze yumurtalık (over) nakli 2005 yılında $^{81}$ ve ilk başarılı rahim (uterus) nakli de 2011 y1lında ${ }^{82}$ gerçekleşmiştir.

\footnotetext{
${ }^{78}$ Semiz, Insan Anatomisi ve Fizyolojisi, 167-168; MEB, Üreme Sistemi, 16-17; MEB, Anne ve Çocuk Să̆ll̆̆ 1,7 .

${ }^{79}$ Semiz, Insan Anatomisi ve Fizyolojisi, 168.

80 “5. Tıbbî Fıkıh Konseyin Sonuç Bildirgesi ve Tavsiye Kararları", Mecelletü'l-Mecma'i'l-Fıkhi'lİslâmî, VI, 2067; “İslâm F1kıh Akademisi'nin 6/8/59 Sayılı Kararı”, Mecelletü'l-Mecma'i'l-Fıkhi'lİslâmî, VI, 2155.

${ }^{81}$ Çetin ve Çetin, "Dünden Bugüne Yardımla Üreme Teknikleri”, 154.

${ }^{82}$ Uğurlu, Antioksidanların Uterus Transplantasyonunda Angiogenezise Etkileri, 27.
} 
Üreme organlarının nakli konusunda genel ilke, 5. Tıbbî F1kıh Konseyi ve İslâm F1kıh Akademisi'nin 14-20 Mart 1990 tarihlerinde Cidde'de düzenlenen altıncı dönem toplantısında belirlenmiştir. Bu kararlara göre, genetik özellikleri taşıyan üreme organlarının nakli caiz değildir; buna karşılık genetik özellikleri taşımayanların nakli ise, organ nakli ile ilgili genel şartlara uyulmak kaydıyla caizdir. ${ }^{83}$ Bu genel ilke doğrultusunda kadın üreme organlarının nakli değerlendirildiğinde, şu sonuçlar çıkarılabilir:

a) Fallop tüpleri tıkalı olan veya tüpleri bulunmayan kadınlar, tüp bebek uygulamasıyla çocuk sahibi olabilmektedir. Hâlbuki organ naklinin caiz olması için gereken şartlardan biri, hastanın hayatını veya hayatî bir uzvunu kurtarmak için bundan başka çare olmadığının tespit edilmesi gerekir. Fallop tüpleri tıkalı olan kadının çocuk sahibi olabilmesi için, fallop tüpü nakli yapılması zorunlu değildir; tüp bebek uygulamasıyla da anne olabilir. Dolayısıyla fallop tüplerinin nakli caiz değildir.

b) Yumurtalıkların olmaması, çalışmaması veya kanser ve erken menopoz gibi sebeplerle kısır olan kadınların çocuk sahibi olabilmesi için uygulanacak tedavi yöntemlerinden biri de yumurtalık/yumurtalık dokusu naklidir. Bu ise, ya kadının kendisinden alınıp dondurularak saklanan yumurtalık dokusunun tekrar kendisine nakledilmesi (ototranplantasyon), ya da başka bir kadından alınan yumurtalık dokusunun nakli (transplantasyon) şeklinde olabilmektedir.

Yumurtalık/yumurtalık dokusunun ototranplantasyonunda, nakledilen doku zaten kadının kendisine ait olduğu için, neslin karışması söz konusu değildir. Dolayısıyla bunun caiz olduğu söylenebilir. Fakat yumurtalık/yumurtalık dokusunun tranplantasyonu, dokunun alındığı kadının genetik özelliklerini naklettiğinden, neslin karışmasına sebep olduğu için caiz değildir. Çünkü ergenlik döneminden itibaren, menopoz dönemine kadar olgunlaşarak fallop tüplerine alınacak yumurta hücreleri, doğuştan yumurtalıklarda gelmektedir. Bunun için bir kadından başka birine yumurtalık dokusu nakledildiğinde, aynı zamanda ona ait yumurtalar da nakledilmektedir. Bunun sonucu olarak da, kişi nikâhlı eşine ait olmayan yumurtadan çocuk sahibi olmaktadır.

Başkasına ait yumurtalık dokusunun nakli caiz olmamakla birlikte, bunu yapanlar çıkarsa, bu durumda, çocuğun nesebi ve sıhriyet hısımlığı bakımından bazı hukuki sonuçlar doğar. İslâm hukukunda çocuğun annesi, kendisini dünyaya getiren kadındır ve kadın çocuğu reddedemez.

\footnotetext{
83 “5. Tıbbî Fıkıh Konseyin Sonuç Bildirgesi ve Tavsiye Kararları”, Mecelletü'l-Mecma'i'l-Fıkhi'lİslâmî, VI, 2067; "İslâm Fıkıh Akademisi'nin 6/8/59 Sayılı Kararı", Mecelletü'l-Mecma'i'l-Fıkhi'lİslâmî, VI, 2155.
} 
Çocuğun babası ise, sahih evlilik, fasit evlilik veya evlilik şüphesiyle kadınla ilişsiye giren kişidir. Buna göre, yumurtalık naklinden sonra dünyaya gelen çocuğun nesebi, kendisini doğuran anne ve eşinden sabit olur. Bununla birlikte, yumurtanın asıl sahibi, kendisinden yumurtalık alınan kadın olduğu için, çocukla arasında evlilik engeli meydana gelir.

c) Yumurtalık fonksiyonları yeterli olmakla birlikte, uterus faktörlü infertilite sebebiyle çocuk sahibi olamayan kadınlar, rahim nakliyle çocuk sahibi olabilmektedirler. Rahim transplantasyonunda, nakledilen organ donörün genetik özelliğini doğacak çocuğa taşımadığ1 için, vefat eden ve menopoza giren kadınlardan, kendileri veya velilerinin izniyle, karşılığında bir ücret alınmaksızın uterus faktörlü infertiliteli kadınlara rahim nakli caizdir. Burada donörün, alıcı kadın veya kocasıyla akraba olup olmaması hükmü etkilemez. 


\section{KAYNAKÇA}

1. "Kardeşler Arası Yumurtalık Nakli", 23.02.2018 tarihinde http://uzunyasam.blogspot.com.tr/2009/08/kardesler-aras-yumurtalk-nakli.html sayfasindan erişilmiştir.

2. "Kardeşler Arası Yumurtalık Nakli", 27.03.2018 tarihinde https://www.turkcebilgi.org/saglik/genetik/kardesler-arasi-yumurtalik-nakli-414.html sayfasından erişilmiştir.

3. "Organ Nakli”, 03.02.2018 tarihinde, https://kurul.diyanet.gov.tr/Karar-MutalaaCevap/9669/organ-nakli sayfasından erişilmiştir.

4. “Tüp Bebek Güncel Haberler”, 27.03.2018 tarihinde, http://www.cyprusivf.net/tup-bebekguncel-haberler/ sayfasından erişilmiştir.

5. “Tüplerin Açılması", 10.02.2018 tarihinde http://www.centrumtupbebek.com/tuplerinacilmasi.html sayfasından erişilmiştir.

6. "Tüplerin T1kal1 (Kapal1) Olmas1", 10.02 .2018 tarihinde, http://www.centrumtupbebek.com/tuplerin-tikali-kapali-olmasi.html sayfasından erişilmiştir.

7. "Yumurtalık ve Rahim Nakli Hayal Değil", 27.03.2018 tarihinde, https://www.saglikaktuel.com/haber/yumurtalik-ve-rahim-nakli-hayal-degil-2593.htm, sayfasından erişilmiştir.

8. "Yumurtalı ve Rahim Nakli Hayal Değil", 27.03.2018 tarihinde http://www.hurriyet.com.tr/kelebek/saglik/yumurtalik-ve-rahim-nakli-hayal-degil-8978150, sayfasından erişilmiştir.

9. 5. Tıbbî Fıkıh Konseyi, (1990) “Sonuç Bildirgesi ve Tavsiye Kararları”, Mecelletü'l-Mecma 'i’lFıkhi'l-İslâmî, Cidde.

10. Abdullah b. Muhammed et-Tayyâr, Abdullah b. Muhammed el-Mutallık, Muhammed b. İbrâhîm el-Mûsâ, (2012) el-Fıkhu'l-Müyesser en-Nevâzilu't-Tıbbiyyetü'l-Mu 'âsıra, Riyad.

11. Abdurrahman el-Bessâm, (1986) "Etfâlu'l-Enâbîb", Mecelletü'l-Mecma'i'l-Fılkhi'l-İslâmî, Cidde.

12. Alâuddîn el-Kâsânî, (1982), Bedâi'u's-Sanâi' fî Tertîbi'ş-Şerâi', Dâru'l-Kitâbi'l-Arabî, Beyrut.

13. Ayşe Şimşek, (2014) "İslâm Hukuku Açısından Taşıyıcı Annelikte Meşruiyet Tartışmaları", İslâm Hukuku Araştırmaları Dergisi, Konya, 24/241-266;

14. Bekir b. Abdullah Ebû Zeyd, (1987) “Turuku'l-İncâb fi't-T1bbi'l-Hadîsi ve Hukmuha'şŞer'iyyu", Mecelletü'l-Mecma'i'l-Fıkhi'l-İslâmî, yy.

15. Belma Derman Semiz, (1990), Insan Anatomisi ve Fizyolojisi, Marmara Üniversitesi Yayınlar1, İstanbul.

16. Birand Taneri, (2015), Acil Servisde Acil Tip Hekimlerinin Organ Bağışı Sürecinde Yönetim, Duyarlılık ve Farkındalıkları, Yayınlanmamış Uzmanlık Tezi, Başkent Üniversitesi Tıp Fakültesi, Ankara.

17. Bülent Tıraş, "Yumurtalık veya Tüplerin Alınması Ameliyatı", 10.02.2018 tarihinde, https://www.bulenttiras.com/yumurtalik-veya-tuplerin-alinmasi-ameliyati, sayfasindan erişilmiştir.

18. Cihan Çetin, M. Turan Çetin, (2014) "Dünden Bugüne Yardımla Üreme Teknikleri”, Arşiv Kaynak Tarama Dergisi, Adana, 23.

19. Çağdaş Doğan, Prematür Ovaryan Yetmezlikle Xpd Ve Xrcc1 Dna Tamir Gen Polimorfizminin İlişskisi, Yayınlanmamış Uzmanlık Tezi, İnönü Üniversitesi Tıp Fakültesi, Malatya 2011.

20. Ebû İshâk eş-Şîrâzî, (1996), el-Mühezzeb, Daru'l-Kalem, Dımeşk.

21. Ebû'l-Hasen Ali b. Sa'îd er-Recrâcî, (2007) Menâhicu't-Tahsîl ve Netâicu Letâifi't-Te'vîl fî̀ Şerhi'l-Müdevveneti ve Halli Müskilâtihâ, Dâru'bni Hazm, Beyrût.

22. Erkan Gümüş, Celal Kaloğlu, İsmail Sarı, Meral Yılmaz, (2016), "Vitrifikasyon Yöntemiyle Dondurulan ve Ototransplantasyonu Yapılan Fare Ovaryum Dokularında Vasküler Endotelyal Kaderin (Ve-Kaderin) Ekspresyonlarının İncelenmesi”, Türk Biyokimya Dergisi, 01.03.2018 tarihinde www.turkbiyokimyadernegi.org.tr/TBDDergisi/TBD-Sivas-Biyokimya-Gunleri.pdf, sayfasından erişilmiştir. 
23. Esra Atabenli Erdemli, Esra Atabenli Erdemli, Ferda Topal, Sinan Özkavukçu, Sibel Serin Kılıçoğlu, Deniz Balc1, (2011), Ovaryum Dokusunun, Vitrifikasyon ve Yavaş Soğutma Teknikleriyle Korunurluğunun Histopatolojik Yönden Karşılaştırılması, Ankara Üniversitesi Bilimsel Araştırma Projesi Kesin Raporu, Ankara, 01.03.2018 tarihinde, http://acikarsiv.ankara.edu.tr/browse/6436/Microsoft\%20Word\%20\%20BAP\%20proje_raporu.pdf sayfasından erişilmiştir.

24. Fahruddîn Osman b. Ali ez-Zeylaî, (1314), Tebyînül-Hakâik Şerhu Kenzi'd-Dekâik, Matbaatu'l-Kübrâ'l-Emîriyye, Bulak.

25. Gülüşan Göce, (2005), "Tüp Bebek Tedavisi Almış Kadınların Dinî Başa Çıkma Süreçleri ve Dini Yaşantıları Üzerine Nitel Bir Araştırma”, İstanbul Üniversitesi İlahiyat Fakültesi Dergisi, İstanbul, 32.

26. Halid Reşîd el-Cemîlî, (1990) "Ahkâmu Nakli'l-Husyeteyni ve'l-Mübeyyidayni ve Ahkâmu Nakli A'dâi'l-Cenîni'n-Nâkısi'l-Hilkati fî'ş-Şerîati'l-İslâmiyye”, Mecelletü'l-Mecma 'i'lFıkhi'l-İslâmî, Cidde.

27. Hayrettin Karaman, (1991), Mukayeseli İslâm Hukuku, Nesil Yayınları, İstanbul.

28. İKÖ İslâm F1kıh Akademisi, (1987), “4 sayılı Tüp Bebek Kararı”, Mecelletü'l-Mecma 'i’lFıkhi'l-İslâmî, yy..

29. İKÖ İslâm Fıkıh Akademisi, (1987) “4/1 nolu Organ Nakli kararı”, Mecelletü’l-Mecma 'i’lFikhi'l-íslâmî, yy.

30. İKÖ İslâm Fikıh Akademisi, (1990), "İslâm Fikıh Akademisi'nin 6/8/59 Sayılı Kararı", Mecelletü'l-Mecma'i'l-Fıkhi'l-İslâmî, Cidde.

31. İlkay Başer Demircan, (2012), Histidin-Triptofan-Ketoglutarat (Htk) Çözeltisine Eklenen Acetyl-L-Carnitin'in Donör Uterus'daki Koruyucu Etkilerinin Araştırılması, (Yayınlanmamış Yüksek Lisans Tezi) Ankara.

32. İrfan Yüce, (2007), "Organ Nakli”, DİA, Ankara.

33. İsmail Aytaç, (2002), "Yardımcı Üreme Tekniklerinin Nesep Hukuku Açısından İncelemesi", Adalet Dergisi, Ankara $\quad 11, \quad 21.04 .2018$ tarihinde, http://www.yayin.adalet.gov.tr/adaletdergisi/11.sayi/5ismail.pdf sayfasindan erişilmiştir.

34. Jane Özcan, (2005), Invitro Fertilizasyon Planlanan Zaylf Yanitl Hastalarda Uygulanan Mikrodoz Protokolü Ille Mikrodoz Stop Protokolünün Karşılaştırılması, Yayınlanmamış Uzmanlık Tezi, Sağlık Bakanlığı Süleymani Kadın Hastalıkları ve Doğum Eğitim ve Araştırma Hastanesi, İstanbul.

35. Kemal Tekin, Ferit Saraçoğlu, (2004), "Overlerin Dondurularak Saklanması”, Kadın Doğum Dergisi, Ankara 2.

36. Kemalüddin Ebu'l-Bekâ Muhammed b. Mûsâ b. Îsâ ed-Demîrî, (2004) en-Necmü'l-Vehhâc fî Şerhi'l-Minhâc, Dâru'l-Minhâc, yy.

37. Mecelle-i Ahkâm-1 Adliyye.

38. Mehmet Musa Aslan, Üniversite Hastanesine Başvuran Fertil ve İnertil Kadınların Yumurta Donasyonu Hakkındaki Düşünceleri, Yayınlanmamış Uzmanlık Tezi, Trakya Üniversitesi Tıp Fakültesi, Edirne 2016.

39. Milli Eğitim Bakanlığı (2012), Çocuk Gelişsimi ve Ĕ̆itimi Anne ve Çocuk Sağlı̆̆l 1, Ankara.

40. Milli Eğitim Bakanlığı (2012), Üreme Sistemi, Ankara.

41. Muhammed Ali el-Bâr, (1987), "el-Kadâyâ'l-Ahlâkiyyetü'n-Nâcimetü ani’t-Tehakkümi fî Takniyyâti'l-İncâb (et-Telkîhu'l-i̇stinâ'î)", Mecelletü'l-Mecma'i'l-Fıkhi'l-İslâmî, yy.

42. Muhammed Ali el-Bâr, (1986), "et-Telkîhu's-Sinâ'î ve Etfâlu'l-Enâbîb”, Mecelletü'lMecma'i'l-Fıkhi'l-íslâmî, Cidde.

43. Muhammed b. Ahmed eş-Şirbînî, (1996), el-Büceyrimi ale'l-Hatîb (el-İknâ' fî̀ Halli Elfâzi Ebî Şucâ'), Dâru'l-Kütübi'l-İlmiyye, Beyrut.

44. Muhammed b. İdrîs eş-Şâfiî, (1393), el-Ümm, Dâru'l-Ma'rife, Beyrut.

45. Muhammed b. Muhammed el-Muhtâr eş-Şenkîtî, (1994), Ahkâmu'l-Cerâhati't-Tibbiyye ve'lÂsâru'l-Müterettibetü aleyhâ, Cidde.

46. Muhammed b. Salih b. Muhammed el-Useymîn, (1422), eş-Şerhu'l-Mümti'alâ Zâdi'l-Müstekni', Dâru İbni'l-Cevzî, yy.,.

47. Muhammed Emin b. Ömer İbn Âbidîn ed-Dımeşkî, (1984), Hâşiyetü Reddi'l-Muhtâr alâ'd- 
Dürrî'l-Muhtâr Şerhi Tenvîri'l-Ebsâr, İstanbul.

48. Muhyiddîn Ebû Zekeriyyâ Yahyâ b. Şeref en-Nevevî, (2005), Minhâcu't-Tâlibîn ve Umdetü'lMüftîn, Dâru'l-Minhâc, Beyrut.

49. Mustafa es-Suyûtî er-Ruhaybânî, (1961), Metâlibu Üli'n-Nühâ fỉ Şerhi Gayeti'l-Müntehâ, elMektebü'l-İslâmî, Dimeşk.

50. Muvaffukuddin Ebû Muhammed Abdullah b. Ahmed İbn Kudâme, (1983), el-Muğnî, Dâru'lKitâbi'l-Arabî, Beyrut.

51. Özlem Așcı, Nezihe Kızılkaya Beji, (2012) "İnfertilite Danışmanlığı”, İstanbul Üniversitesi Florence Nightingale Hemşirelik Dergisi, İstanbul, 20.

52. Özlem Moraloğlu Tekin, Eylem Ünlübilgin, "Yardımcı Üreme Tekniklerinde Tubal Cerrahi", Türk Üreme Tibbl ve Cerrâhisi Dergisi, 10.02.2018 tarihinde, http://www.tjrms.org/currentissue/get-pdf/30/148092364901829.pdf, sayfasından erişilmiştir.

53. Pınar Doğan, (2009) Afyon Kocatepe Üniversitesi Öğrencilerinin Organ Bağışı Konusundaki Bilgi Tutum Ve Davranışları, Yayınlanmamış Yükseklisans Tezi, Afyon Kocatepe Üniversitesi Sağlık Bilimleri Enstitüsü, Afyon.

54. Rabıtatü'l-Alemi'l-İslâmî bünyesinde bulunan İslâm F1kıh Akademisi, (1986), "et-Telkîhu'sSınâ'î ve Etfâlu'l-Enâbîb" kararı, Mecelletü'l-Mecma'i'l-Fıkhi'l-İslâmî, Cidde.

55. Remlî, Şemsüddin Muhammed b. Ebû'l-Abbâs Ahmed b. Hamza İbn Şihabiddîn er-Remlî, (1993) Nihâyetü'l-Muhtâc ilâ Şerhi'l-Minhâc fi'l-Fıkhi alâ Mezhebi'l-İmâm eş-Şâfî̀, Dâru Kütübi'l-İlmiyye, Beyrut.

56. Ruşen Öztürk, Ümran Sevil, (2013), "Uterus Transplantasyonu ve Etik”, Gümüşhane Üniversitesi Sağlık Bilimleri Dergisi, Gümüşhane, 2.

57. Sa'îd b. Muhammed Bâ-Alî Bâişin ed-Dev'anî el-Hadramî, (2004), Şerhu'l-Mukaddimeti'lHadramiyye (Büşra'l-Kerîm bi-Şerhi Mesâili't-Ta'lîm), Dâru'l-Minhâc, Beyrut.

58. Selami Kara, Zeliha Salman, Kurtuluş Öngel,(2012), "Süleyman Demirel Üniversitesi Tıp Fakültesi Sağlık Personelinin Organ Bağışına Bakışı”, Ankara Sağlık Hizmetleri Dergisi, Ankara, 1.

59. Serahsi, Şemsü' l-eimme Ebû Bekr Muhammed b. Ebî Sehl es-Serahsî, Kitâbu'l-Mebsût, Dâru'lMâ'rife, Beyrut ty.

60. Seval Taşdemir, "Hidrosalpenks Nedir?", 10.02.2018 tarihinde, https://www.sabah.com.tr/yazarlar/seval-tasdemir/2015/03/21/hidrosalpenks-nedir sayfasindan erişilmiştir.

61. Sinan Özkavukçu, (2014), "Ovaryum Kriyoprezervasyonunun Folikülogeneze Etkileri”, XII. Ulusal Histoloji ve Ebriyoloji Kongresi Kongre Program ve Özet Kitabl, Ankara.

62. Soner Çelik, (2016) Ovaryum Kriyoprezervasyonu ve Transplantasyonu Sonrasında Folikül Kaybı Mekanizmalarında Rol Alan Baskılayıcı Moleküllerin Araştııılması, Yayınlanmamış Yüksek Lisans Tezi, Akdeniz Üniversitesi Sağlık Bilimleri Enstitüsü, Antalya.

63. Şeyhmus Tunç, Spontan Yoldan Ve Yardımcı Üreme Teknikleri İe Gebe Kalan Hastaların Maternal, Fetal ve Perinatal Özelliklerinin Karşılaştırılması, (Yayınlanmamış Uzmanlık Tezi), Malatya 2014.

64. Şirbînî, Şemsüddîn Muhammed b. el-Hatîb eş-Şirbînî, (1997), Muğni'l-Muhtâc ilâ Ma'rifeti Me'âni Elfâzi'l-Minhâc, Dâru'l-Ma'rife, Beyrut.

65. Talat Ahmed el-Kasbî, (1990), “İmkâniyyetü Nakli'l-A'zâi't-Tenâsüliyye fî'l-Mer'e", Mecelletü'l-Mecma'i'l-Fıkhi'l-İslâmî, Cidde.

66. Tuğba Uğurlu, (2017), Antioksidanların Uterus Transplantasyonunda Angiogenezise Etkileri, Yayınlanmamış Yüksek Lisans Tezi, Gazi Üniversitesi Sağlık Bilimleri Enstitüsü, Ankara.

67. Türk Medenî Kanunu.

68. Ülfet Görgülü, (2010) “Taşıyıcı Annelik -Fıkhi Bir Bakış-”, İslâm Hukuku Araştırmaları Dergisi, Konya, 15, 197-208.

69. Vehbe Zuhaylî, (1985), el-Fıkhu'l-İslâmî ve Edilletuhu, Daru'l-Fikr, Dimeşk.

70. Yasemin Erol, (2011), Yapay Döllenme Yöntemleri ve Taşıyıcı Annelik, Yayınlanmamış Doktora Tezi, Selçuk Üniversitesi Sosyal Bilimler Enstitüsü, Konya. 


\section{Summary}

Every married couple wants to have children. However, some couples cannot be parents. The statu of nonoccurrence or discontinuity of pregnancy for one year despite the fact that couples in reproductive age want to have a baby is called medically infertility. The absence of their children deeply affects the couples and their families. Because having children does not only provide the continuation of the generation but also has a vital meaning with its sociological, psychological, spiritual and moral dimensions. For this reason, childless couples mobilize all opportunities to have baby. With the help of assisted reproductive methods, many of these couples can have one.

The first successful in vitro fertilization study was carried out in 1976 and it has made a great progress since then. This issue has been evaluated in many meetings and studies in terms of Islamic law since it has been a long time since application of IVF. However, the first successful fresh ovarian transplantation was performed in 2005 and the first successful uterus (uterus) transplantation was performed in 2011. For this, transplantation of reproductive organs is yet a new issue.

The general principle on the transplantation of reproductive organs has been determined at the sixth session of the 5th Jurisprudence Council and the Islamic Fiqh Academy on 14-20 March 1990 in Jeddah. According to these decisions, it is not permissible to transplant genetically engineered reproductive organs; as regards transplantation of those who do not have genetic characteristics, it is permissible on condition of providing general stipulations for organ transplantation. By evaluating the transplantation of female reproductive organs in accordance with this general principle, the following conclusions can be drawn:

a) Women with clogged of fallopian tube or have no tube may have a baby via IVF. For this reason, a fallopian tube transplant is not necessary for such women to become mother. As a matter of fact, one of the legitimacy conditions for organ transplantation in fiqh is that there is no other cure to save the patient's life or a vital part. On the other hand, there are risks in terms of both donor and recipient in the surgery for tube transplantation. Accordingly, transplantation of fallopian tubes is not permissible.

b) In order to have a child, one of the methods of treatment for the women who does not have any ovaries, or who are infertile due to reasons such as cancer and premature menopause, is to transplant ovarian / ovarian tissue. This can take place of either the form of transferring frozen and stored ovarian tissue belonging to her (autotransplantation), or transplanting the the tissue from another woman.

In the ototranplantation of ovarian / ovarian tissue, the generation decay (lineage confusion) does not occur since the transplanted tissue belongs to the woman itself, Therefore it can be said that it is permissible. However, transplantation of ovarian / ovarian tissue is not permissible as it causes lineage confusion with the genetic characteristics of the female. This is so because, from adolescence to menopausal period, the matured egg cells which are taken into the fallopian tubes come from the congenital ovaries. For this purpose, when the ovary tissue is transplanted from one woman to another, the eggs are also transplanted. As a result, the person has a child who does not belong to his spouse.

It can be suggested here the transfer of the ovary tissue taken from one of the spouses, to the other one, as in the surrogate motherhood, But it is always possible for the husband to die or to leave his wife who has undergone an ovarian transplant. In this case, the egg cells in the ovaries belong to the the previous wife. If she later gets married and becomes pregnant by her 


\section{Paçacı}

new husband, she will be able to become pregnant with her new husband's sperm and, egg of her former husband's wife. This is haram, because it causes the the generation decay. Therefore, it is not permissible to transfer the ovarian tissue from one of the spouses to the other.

Although transplantation of the ovarian tissue of someone else is not permissible, if it is to be done some legal consequences arise on the child's sub-lineage and marriage relationship. In Islamic law, the child's mother is the woman who brought her to the world, and she cannot refuse the child. As a matter of fact, in the Qur'an, "Their mothers are only women who give birth them". The child's father is the person who has intercourse with the woman on the basis of a legal marriage, a corrupt (fasid) marriage or a suspicious marriage. Because the Prophet (p.u.h.) said, "The child belongs to the person who is legitimate to be with his mother; for the adulterer there is deprivation." According to this, the birth of the child born after ovarian transplantation, the mother and the wife that gives birth to be fixed. However, since the original owner of the egg is the woman from whom the ovary received, a marriage barrier occurs with the child.

c) Although ovarian functions are adequate, the women who cannot have children due to uterine factor infertility can have children by uterine transplantation. In uterine transplantation, the transplanted organ do not carry the genetic characteristics of the donor to the child. Because of this, it is permissible to transfer the uterus from the dead or menopausal women to ones with infertility with uterine factor, with the permission of themselves or their parents. To be kinship of the donor with the receiving woman or her husband does not affect the provision. 7

Keywords: İnfertility, fallopian tubes transplantation, ovarian transplantation, uterus transplantation, organ transplantation. 